\title{
Tidal Asymmetry in Ocean-Boundary Flux and In-Estuary Trapping of Suspended Sediment Following Watershed Storms: San Francisco Estuary, California, USA
}

\author{
Maureen A. Downing-Kunz ${ }^{1,2}$ (D) $\cdot$ Paul A. Work ${ }^{1} \cdot$ David H. Schoellhamer $^{3}$ \\ Received: 6 December 2019 / Revised: 14 February 2021 / Accepted: 8 March 2021 / Published online: 18 March 2021 \\ (C) The Author(s) 2021, corrected publication 2021
}

\begin{abstract}
Suspended-sediment flux at the ocean boundary of the San Francisco Estuary - the Golden Gate - was measured over a tidal cycle following peak watershed runoff from storms to the estuary in two successive years to investigate sediment transport through the estuary. Observations were repeated during low-runoff conditions, for a total of three field campaigns. Boat-based measurements of velocity and acoustic backscatter were used to calculate water and suspended-sediment flux at a location $1 \mathrm{~km}$ landward of the Golden Gate. Suspended-sediment concentration (SSC) and salinity data from up-estuary sensors were used to track watershed-sourced sediment plumes through the estuary. Estimates of suspended-sediment load from the watershed and net suspended-sediment flux for one up-estuary subembayment were used to infer in-estuary trapping of sediment. For both poststorm field campaigns, observations at the ocean boundary were conducted on the receding limb of the watershed hydrograph. At the ocean boundary, peak instantaneous suspended-sediment flux was tidally asymmetric and was greater on flood tides than on ebb tides for all three field campaigns, due to higher average SSC in the cross-section on flood tides. Shear-induced sediment resuspension was greater on flood tides and suggests the presence of an erodible pool outside the estuary. The storms in 2016 led to less export of discharge and sediment from the watershed and greater sediment trapping within one up-estuary subembayment compared to that observed in 2017. Results suggest that substantial trapping of watershed sediments occurred during both storm events, likely due to the formation of estuarine turbidity maxima (ETM) at different locations in the estuary. ETM locations were forced nearer the ocean boundary in 2017. Additional measurements and modeling are required to quantify the long-term sediment flux at the Golden Gate.
\end{abstract}

Keywords Suspended-sediment flux · San Francisco Estuary · Estuaries · Coastal transport · Sediment management

\section{Introduction}

The transport of sediment through an estuary affects sediment availability, which in turn affects ecosystem primary production, contaminant transport and fate, and navigation and dredging operations. Sediment availability in estuaries is

Communicated by Mead Allison

Maureen A. Downing-Kunz

mokunz@gmail.com

1 U.S. Geological Survey, California Water Science Center, $6000 \mathrm{~J}$ Street, Placer Hall, Sacramento, CA 95819, USA

2 Present address: Environmental Science Associates, 2600 Capitol Avenue, Suite 200, Sacramento, CA 95816, USA

3 U.S. Geological Survey, 2130 SW 5th Avenue, Portland, OR 97201 , USA affected by the processes of sediment delivery, transport and trapping, and outflow to the ocean. These processes can be difficult to quantify for a given estuary (e.g., Geyer et al. 2004; McKee et al. 2013).

For the case of the San Francisco Estuary (SFE) in California, sediment delivery and transport processes have been relatively well studied (e.g., Schoellhamer 2011; Barnard et al. 2013; McKee et al. 2013; Schoellhamer et al. 2018), but sediment outflow to the ocean remains the most poorly understood component of the estuary-wide sediment budget (Schoellhamer et al. 2005; Erikson et al. 2013). For example, the sediment budget computed in Schoellhamer et al. (2005) inferred sediment outflow at the ocean boundary (Golden Gate Bridge, Fig. 1) as the residual term of an estuary-wide sediment budget. Sediment outflow at the ocean boundary of SFE following storms has been observed via remote sensing (Ruhl et al. 2001), but existing field observations of sediment exchange 


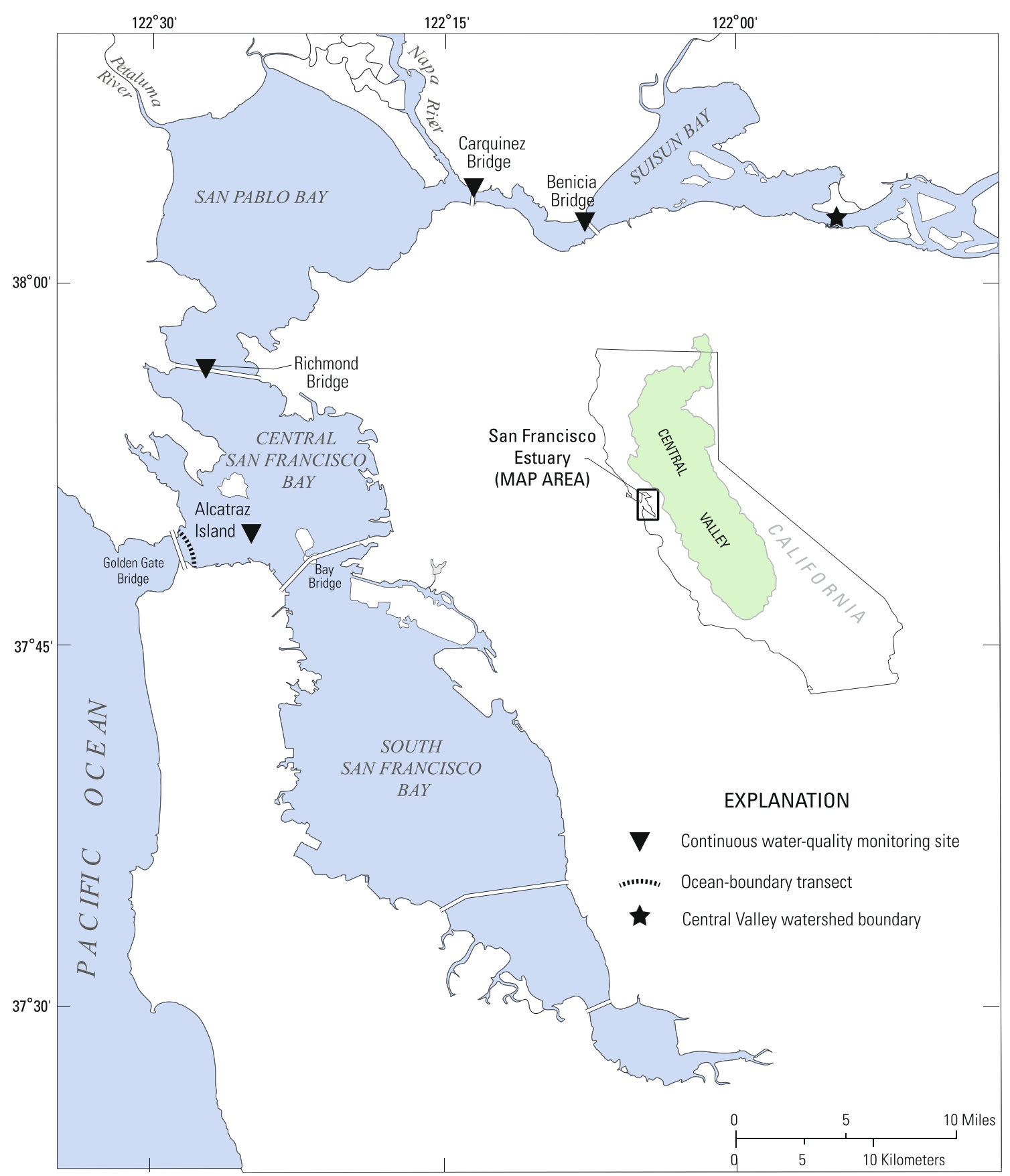

Fig. 1 Map of San Francisco Estuary, California, USA. Location of short-term, boat-based field measurements is $1 \mathrm{~km}$ east (landward) of the Golden Gate Bridge, denoted by dashed arc. Up-estuary salinity and suspended-sediment concentration data were obtained from long-term water-quality monitoring stations, denoted by inverted triangles. Watershed inflow of freshwater and sediment are computed at the Central Valley watershed boundary, denoted by a star. Central Valley watershed area denoted in green (inflow and outflow) at the ocean boundary are relatively sparse: Teeter et al. (1996) conducted field measurements during dry-weather conditions in 1988 and 1992; and Erikson et al. (2013) conducted field measurements during a below-average wet season of 2008. The paucity of field observations of sediment exchange at the ocean boundary of SFE is attributed to difficult conditions arising from its physical characteristics: the inlet width exceeds $1.5 \mathrm{~km}$,
$100 \mathrm{~m}$ in depth, and experiences semi-diurnal tides with a tidal range of nearly $2 \mathrm{~m}$, giving rise to tidal currents in excess of $2 \mathrm{~m} / \mathrm{s}$. Additionally, the exchange of water at the ocean boundary at the tidal time scale far exceeds that at the subtidal or net time scale, which can introduce large uncertainty when determining net flow.

The SFE (Fig. 1) is the largest estuary on the western coast of North America. The watershed of SFE encompasses nearly 
$40 \%$ of California's land area (over $162,000 \mathrm{~km}^{2}$ ) and is generally considered to have two primary regions (e.g., McKee et al. 2013): the Central Valley, which includes the Sacramento River and San Joaquin River and their tributaries (95\% of the total watershed area), and the local tributaries, which includes the smaller watersheds adjacent to and transporting inflow into SFE (5\% of the total watershed area). Freshwater inflow from the Central Valley enters the estuary at the northeastern boundary (Fig. 1). Over recent history, research has shown that sediment delivery from the Central Valley has decreased (Porterfield 1980; Schoellhamer et al. 2018), indicating an increase in the relative contribution from the local tributaries. Despite its decreasing sediment contribution, the Central Valley supplies most of the freshwater to SFE (more than 90\%; Conomos 1979; McKee et al. 2013) and sets the estuary as a river-forced system. Freshwater inflow to an estuary is one factor affecting estuarine circulation and sediment trapping (Geyer and MacCready 2014; Burchard et al. 2018). Thus, observing ocean outflow following storms in the Central Valley watershed provides information about riverforced sediment trapping within SFE.

The objective of this study was to measure suspendedsediment flux at the ocean boundary and infer sediment trapping for the river-forced system of SFE through field observations of water and suspended-sediment flux at the tidal timescale during varying hydrologic conditions. The focus of this work is measuring sediment outflow to the ocean in the context of short-term transport and storage within the river-forced system, to provide data to support future efforts to refine the sediment budget for SFE. Observations were made following two storm events in the Central Valley watershed and during one drysummer season. The March 2016 campaign was after a storm following a long period of drought (2012-2015); and the February 2017 effort was near the end of a record-setting wet season (CDWR 2018). The dry period campaign occurred in June 2016, during the region's typical dry-summer conditions.

\section{Methods}

Acoustic-based measurements of water discharge and suspended-sediment concentration (SSC) at a cross-section near the ocean boundary of SFE (Golden Gate Bridge, Fig. 1) were used to estimate suspended-sediment flux over varying tidal and hydrologic conditions. Water samples collected in situ were used to develop a relation between acoustic backscatter and SSC. Up-estuary water-quality data and estimates of watershed discharge and sediment load were used to determine timing of field campaigns and infer sediment trapping processes within the estuary.

\section{Boat-Based Measurements of Water Velocity and Acoustic Backscatter}

At a defined cross-section ("transect"), approximately $1 \mathrm{~km}$ landward of the ocean boundary of SFE (Fig. 1), threedimensional velocity, bottom depth, and echo intensity data were collected using a boat-mounted acoustic Doppler current profiler (ADCP, Workhorse $600 \mathrm{kHz}$, Teledyne RD Instruments, San Diego, CA). The ADCP was deployed in down-looking mode from the San Francisco State University's 12-m R/V Questuary during the March 2016 and February 2017 field campaigns, and from the USGS' 8$\mathrm{m} R / V$ Dinehart in June 2016. ADCP data were acquired with $50-\mathrm{cm}$ vertical resolution at $1 \mathrm{~Hz}$. Echo intensity (in counts) from each of the ADCP beams was converted to sedimentcorrected acoustic backscatter (ABS, in decibels, dB) by accounting for sound absorption, beam spreading, and sediment attenuation (Landers et al. 2016), yielding the average ABS in each depth cell.

The primary outputs from the ADCP utilized in this study were vertical profiles of velocity, depth, and ABS from known locations in horizontal space (based on ADCP bottom track and/or GPS data) at $1 \mathrm{~Hz}$; from these data, the spatial distribution of water velocity and ABS were estimated for each transect. Because the ADCP is deployed just beneath the surface of the water, the near-surface region (this study: $0-1 \mathrm{~m}$ from surface) was not sampled. Due to irregularities in the bed surface, the ADCP ignores signal return and does not compute velocity nor $\mathrm{ABS}$ in the near-bed region, defined as $6 \%$ of the distance between the transducers and the bed plus one depth bin (Teledyne RD Instruments 2016), or in this study: 5-10 m from bed; however, the total depth is observed. In addition, the boat cannot access the entire width of the transect due to shallow regions along both shores. The result is that velocity and $\mathrm{ABS}$ are not measured for about $10 \%$ of the cross-section; occasional communication errors between the ADCP and computer led to additional missing data. Instrument position and heading in space were determined from ADCP bottom track, where possible, or boat GPS data otherwise. Missing velocity data near the surface and bed were filled using hydraulic theory (Simpson and Oltmann 1993; Chen 1991) while missing velocity (and ABS) data from the water column within the sampled region were filled via linear interpolation in the horizontal direction for gaps with lengths less than $50 \mathrm{~m}$ and bounded by good data (i.e., no extrapolation).

\section{Relation of Acoustic Backscatter to Suspended- Sediment Concentration}

Sediment in the water column both reflects and dissipates the energy of sound propagating through the water and is a major component of acoustic backscatter, which has been used as a proxy for SSC (Gartner 2004; Wall et al. 2006; Landers et al. 
2016). To develop the proxy, concurrent observations of sediment-corrected acoustic backscatter (ABS) and in situ water samples analyzed for SSC were collected. Water samples were also analyzed for mass fractions of fine- and sand-sized particles (diameter less than or greater than $63 \mu \mathrm{m}$, respectively). Because the acoustic response of sediment is dependent on the instrument frequency, the same frequency ADCP was used for all field measurements, and water samples were collected during each field campaign. Note that for calibration purposes, it is not necessary to obtain water samples from the same transect where the velocity data are being collected, nor at the same time, but samples must be representative of the environment of interest, and it is desirable to span a wide range of conditions. Due to logistical restrictions, we collected calibration samples at a different time and location than for suspended-sediment flux observations. Given the proximity in space and time between collection of calibration dataset and transect dataset, and the similar range of conditions observed, we assume the general characteristics of suspended sediment are sufficiently similar for these two datasets to produce adequate calibration curves that relate ABS to SSC.

The methodology for collection of suspended-sediment samples differed between the three field campaigns. In March 2016, a boat-mounted, depth-integrating, isokinetic sampler with a mass of $60 \mathrm{~kg}$ (Model D-96; Federal Interagency Sedimentation Project 2001; Davis 2005) was used. This sampler is lowered gradually and steadily through the water column with an open nozzle and thus yields a depthintegrated estimate of velocity-weighted SSC. During the June 2016 and February 2017 field campaigns, a boatmounted, point-integrating, isokinetic sampler with a mass of $48 \mathrm{~kg}$ (Model P-61-A1; Edwards and Glysson 1999; Davis 2005) was used. This sampler has a solenoid to allow nozzle opening for a specified duration at a depth of interest, providing a time-integrated sample at a given depth.

To develop a calibration curve relating ABS to SSC, ordinary least squares regression analysis was used, with $\mathrm{ABS}$ as the explanatory variable for log-transformed SSC, as follows:

$\log _{10} S S C=b_{0}+b_{1} * A B S$

where

SSC suspended-sediment concentration in $\mathrm{mg} / \mathrm{L}$;

$A B S$ sediment-corrected acoustic backscatter in $\mathrm{dB}$;

$b_{0} \quad$ y-intercept; and

$b_{1} \quad$ slope

To estimate SSC from ABS, this log-transformed linear model is retransformed as:

$S S C=10^{\left(b_{0}+b_{1} * A B S\right)} * B C F$

where $B C F=$ bias-correction factor to account for retransformation bias (Rasmussen et al. 2009).
For depth-integrated (D-96) suspended-sediment samples, ABS used in the regression was computed as the average value from the ADCP's four acoustic beams over the vertical extent of the region sampled and over the entire time the D-96 sampler was in the water (generally $\sim 2 \mathrm{~min}$ ). For point, timeintegrated (P-61-A1) samples, ABS was computed as the mean of the four beams across the depth bin nearest the sample depth over the time the sampler nozzle was open (sample duration range: $0.75-1.5 \mathrm{~min}$ ).

\section{Computation of Water Flux, Transect-Average SSC, Suspended-Sediment Flux, and Velocity Shear}

From each transect, the spatial distributions of water velocity and ABS at the ocean boundary were observed. From water velocity distributions, water flux (discharge, $Q$ ) was computed as follows (Simpson and Oltmann 1993; Mueller and Wagner 2009):

$$
Q=\int_{0}^{T} \int_{0}^{D}\left(\overrightarrow{V_{w}} \times \overrightarrow{V_{b}}\right) \cdot \widehat{k} d z d t
$$

where

$$
\begin{aligned}
& \overrightarrow{V_{w}}=u_{w} \widehat{i}+v_{w} \widehat{k} \quad \text { water }(w) \text { velocity vector (x-direction: } u \text {; } \\
& \text { y-direction: } v \text { ) relative to north; } \\
& \overrightarrow{V_{b}}=u_{b} \widehat{i}+v_{b} \widehat{k} \quad \text { boat }(b) \text { velocity vector relative to north, } \\
& \text { determined from ADCP bottom track or } \\
& \text { boat GPS track; } \\
& T \quad \text { elapsed time over which transect data } \\
& \text { collection took place; and } \\
& \text { D local water depth along increment of } \\
& \text { boat track } d z \text {. }
\end{aligned}
$$

The flux of water through a single measurement bin is thus:

$Q=\left(u_{w} v_{b}-v_{w} u_{b}\right) \Delta t \Delta z$

where $\Delta t$ is the time between velocity pings and $\Delta z$ is the vertical bin size.

From ABS distributions, SSC was computed for every bin by applying Eq. (2). Transect-average SSC, used to compare SSC between transects, was computed as the dischargeweighted mean of SSC in all bins. For each bin of a transect, suspended-sediment flux $\left(Q_{s}\right)$ was computed as the product of SSC and Q (Eq. 4):

$Q_{s}=\operatorname{SSC}\left(\mathrm{u}_{w} v_{b}-v_{w} u_{b}\right) \Delta t \Delta z$

The total fluxes of water and suspended sediment for each transect were computed by integrating over the transect. Discharge in unmeasured regions, estimated within ADCP software (Teledyne RD Instruments 2016), was added to determine the final value of water flux. Cross-sectional flow area (A) was computed perpendicular to the mean flow (Teledyne 
RD Instruments 2016). Data from the study are available in Downing-Kunz et al. (2018).

To evaluate the role of shear-induced sediment resuspension in observed $Q_{s}$ at the ocean boundary, an analysis of shear versus SSC was conducted for each ADCP transect. Bottom shear stress scales approximately with the square of velocity (Grant and Madsen, 1986), and, if resuspension dominates, greater shear stress would give rise to greater SSC. In this analysis, we computed velocity $(V)$ as the total discharge $(Q)$ divided by the flow area $(A)$. We represent shear as the product $V|V|$ to preserve the sign, with negative values indicating flood tide. To assess tidal asymmetry, we performed linear regression of $V|V|$ versus SSC for flood-tide data in each field campaign and then assumed tidally asymmetric conditions would produce the same fit line for ebb-tide data, but with opposite slope. Comparison of ebb-tide data to this fit line predicted from flood-tide data provided a qualitative measure of tidal asymmetry in bottom shear stress at the ocean boundary.

\section{Up-Estuary Water Quality and Watershed Inflow of Freshwater and Sediment}

Salinity and SSC at up-estuary locations within SFE were obtained from continuous water-quality monitoring stations at Benicia Bridge (USGS station ID 11455780), Carquinez Bridge (salinity only; USGS station ID 11455820), Richmond Bridge (USGS station ID 375607122264701), and Alcatraz Island (USGS station ID 374938122251801) (Fig. 1). At these monitoring stations, data are collected at one or two depths every $15 \mathrm{~min}$; provisional data are transmitted hourly and are accessible via the National Water Information System website (http://waterdata.usgs.gov/ nwis). More details are available in Livsey and DowningKunz (2020). Tidal filtering of salinity and SSC time series was performed using a low-pass Butterworth filter with a 30-h stop period and a 40-h pass period. Vertical salinity gradients were computed for three stations with sensors at two depths as the difference in tidally filtered salinity divided by the difference in sensor height (near-bed minus mid-depth).

Freshwater inflow to SFE, discharged from the Central Valley watershed, was estimated as the daily averaged net outflow computed from the DAYFLOW model (CDWR 1986), referred to as "Central Valley discharge". The mass loading of suspended sediment into SFE from the Central Valley watershed was computed using the methodology of McKee et al. (2006); the location at which this is computed also forms the landward boundary of the Suisun Bay subembayment (Fig. 1). Net suspended-sediment mass loading at the seaward boundary of the Suisun Bay subembayment (Benicia Bridge, Fig. 1) was computed using the methods of Ganju and Schoellhamer (2006). Net mass deposition (trapping) of suspended sediment within the Suisun Bay subembayment was computed as the difference in daily averaged suspended-sediment load at the landward and seaward boundaries of Suisun Bay. To compare field campaigns, watershed contributions of water and sediment, and Suisun Bay sediment load and deposition were summed and averaged over the entire water year (WY, spanning Oct 1 through Sep 30) preceding measurements at the ocean boundary.

\section{Timing of Field Campaigns}

The timing of field campaigns was determined based on a combination of storm intensity and hydrologic conditions in the Central Valley, water-quality data at up-estuary locations, tidal conditions, previous studies, and crew and vessel availability. Central Valley discharge and discharge into the floodcontrol structure Yolo Bypass (USGS station ID 11453000) were used as indicators of watershed-storm intensity and hydrologic conditions. Water-quality data at up-estuary locations were used as indicators of the transport of sediment-laden watershed outflow through the estuary. Spring tides were selected for field measurements because of the expected higher likelihood of capturing watershed-sourced sediment plumes. During spring tides, tidal excursions are greater, which would transport watershed-sourced plumes closer to the ocean boundary, and tidal velocities are higher, which would increase vertical mixing (Simpson et al. 1990; Schoellhamer 2002). Based on previous work (Erikson et al. 2013), an 8to 12-day lag in peak sediment concentration was expected between the head and mouth of the estuary. For the lowinflow field campaign, a period of low Central Valley discharge during a spring tide was targeted.

\section{Results}

\section{Field Campaigns and Hydrologic Conditions}

Field measurements of water and sediment flux at the ocean boundary of SFE were conducted over a complete tidal cycle following peak discharge from the Central Valley watershed in 2016 and 2017, and during low-flow conditions in 2016 (Fig. 2). See Table 1 for a summary of each field campaign.

In 2016, following a series of watershed storms, Central Valley discharge increased in early March 2016 to a peak value of $4100 \mathrm{~m}^{3} / \mathrm{s}$ on 16 March 2016 (Fig. 3a; Table 1), while flood waters spilled into one flood-control structure (Yolo Bypass on Sacramento River) 12-22 March, with peak flow of $2300 \mathrm{~m}^{3} / \mathrm{s}$ on 15 March (Fig. 3a). Downstream in the estuary, salinity decreased and SSC increased at SFE stations (Fig. $3 \mathrm{~b}-\mathrm{c}$ ) during this period. The high-inflow field campaign was conducted 21-22 March with the ebb tide sampled on 21 March and the flood tide sampled on 22 March. The lowinflow field campaign was conducted for subsequent ebb 


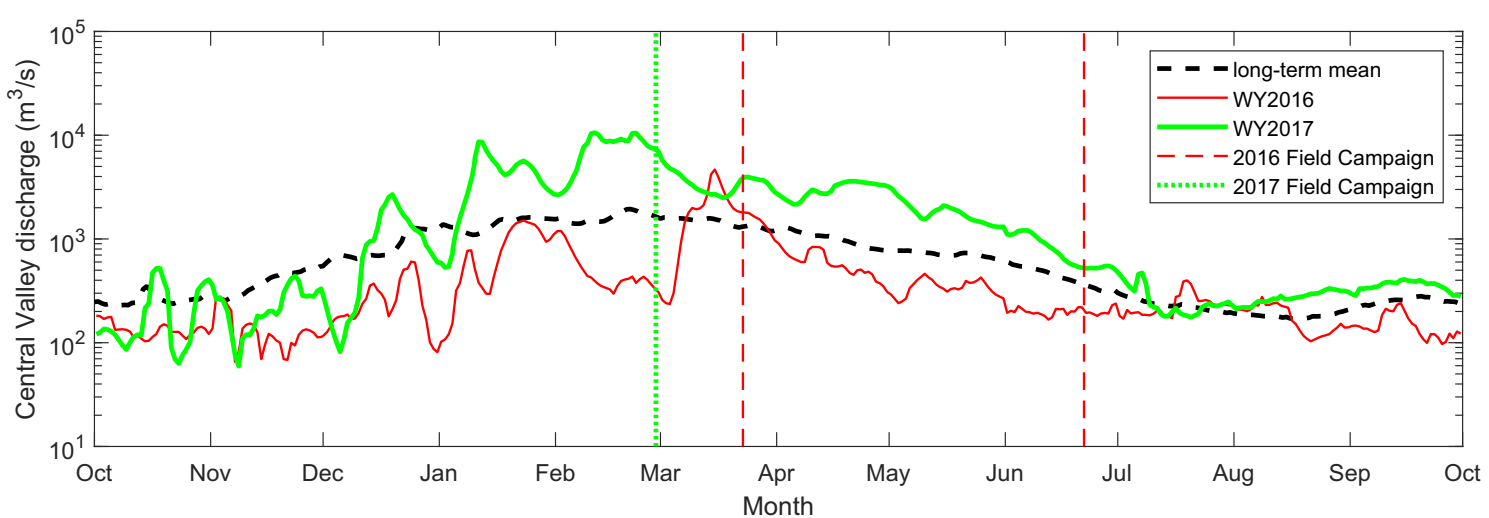

Fig. 2 Comparison of water year (WY) 2016 (thin red line) and 2017 (thick green line) modeled, daily averaged freshwater flow from the Central Valley watershed to long-term mean daily values for WY 1956-2018 (dashed dark line). Vertical dashed lines denote midpoint of
2016 high-inflow (21 Mar 2016 23:05:30 Pacific Standard Time, PST, in red), 2016 low-inflow (23 Jun 2016 09:52:00 PST, in thin red), and 2017 high-inflow (27 Feb 2017 19:00:00 PST, in thick green) field campaigns and flood tides on 23 June 2016 during a period of low freshwater inflow (Fig. 3a; Table 1).

For the Central Valley watershed, 2017 was much wetter than in 2016; in terms of precipitation indices for eight stations in the northern Sierra Nevada Mountains (within the Central Valley watershed of SFE), 2017 was the wettest year on record (CDWR 2018). Precipitation indices during January 2017 and February 2017 were 2.6 and 2.9 times higher, respectively, than the long-term monthly average (CDWR 2018). The magnitude of the peak freshwater inflow to SFE (as estimated by Central Valley discharge) was 2.6 times larger in 2017 compared to 2016 (Table 1 and Fig. 2). In 2017, Central Valley discharge reached a peak value of $10,600 \mathrm{~m}^{3} / \mathrm{s}$ on $11 \mathrm{Feb} 2017$ and remained above $8000 \mathrm{~m}^{3} / \mathrm{s}$ during much of February, until another round of storms and reservoir releases produced a secondary peak value of $9500 \mathrm{~m}^{3} / \mathrm{s}$ on 22 Feb 2017 (Fig. 4a). The Yolo Bypass flood-control structure on the Sacramento River was in use between 9 Jan 2017 and 3 May 2017 (114 days), with peak inflow of $5500 \mathrm{~m}^{3} / \mathrm{s}$ on 22 Feb 2017 (Fig. 4a). The freshwater inflow volume in 2017, computed by summing daily averaged Central Valley discharge volume from beginning of WY to sampling date, was approximately three times greater in $2017\left(3.3 \mathrm{e} 10 \mathrm{~m}^{3}\right)$ compared to $2016\left(9.6 \mathrm{e} 09 \mathrm{~m}^{3}\right)$; in response, near-bed salinities at
SFE stations were lower in magnitude for a longer duration in 2017 than 2016 (Figs. 3b and 4b). Tidally filtered near-bed salinity at Carquinez Bridge reached zero for nearly one month (9 Feb 2017-3 Mar 2017, 22 days, Fig. 4b), indicating the watershed-sourced freshwater plume extended west beyond this location into the San Pablo Bay subembayment (Fig. 1). The field campaign in 2017 was conducted for subsequent flood and ebb tides on 27-28 Feb 2017.

\section{Boat-Based Observations at the Ocean Boundary}

The boat-based observations produced complete and usable ADCP transects during each field campaign. (March 2016: $n$ = 18; June 2016: $n=7$; February 2017: $n=32$ ). Compared to velocity data, ABS data generally required less interpolation because velocity data computation requires greater correlation between beams, while ABS data do not.

An example of the spatial distribution of velocity magnitude derived from a processed (i.e., after any interpolation) transect is shown in Fig. 5, for the transect beginning 13:11 PST on 21 Mar 2016 (Appendix Table 5). For this transect, the net water flux direction was ebb-tide directed (out of SFE; seaward), with higher velocities in the region of elapsed distance between 2.5 and $3.0 \mathrm{~km}$ (Fig. 5). Not shown but evident
Table 1 Summary of field campaigns for measurement of water flux and sediment flux at the ocean boundary - sampling dates, hydrologic conditions in Central Valley watershed, range of observed transect- average suspended-sediment concentration (SSC) at ocean boundary, and peak freshwater inflow from the Central Valley watershed preceding sampling

\begin{tabular}{llll}
\hline Sampling date & Hydrologic conditions & $\begin{array}{l}\text { Range of observed transect-average SSC } \\
\text { at ocean boundary }(\mathrm{mg} / \mathrm{L})\end{array}$ & $\begin{array}{l}\text { Peak of daily averaged Central Valley discharge } \\
\text { prior to sampling }\left(\text { value in } \mathrm{m}^{3} / \mathrm{s}, \text { date) }\right.\end{array}$ \\
\hline 21-22 Mar 2016 & High inflow & $16.9-33.4$ & $4100,3 / 16 / 16$ \\
23 Jun 2016 & Low inflow & $20.4-34.8$ & $200,6 / 20 / 16$ \\
27 Feb 2017 & Very-high inflow & $36.9-68.0$ & $10,600,2 / 11 / 17$ \\
\hline
\end{tabular}



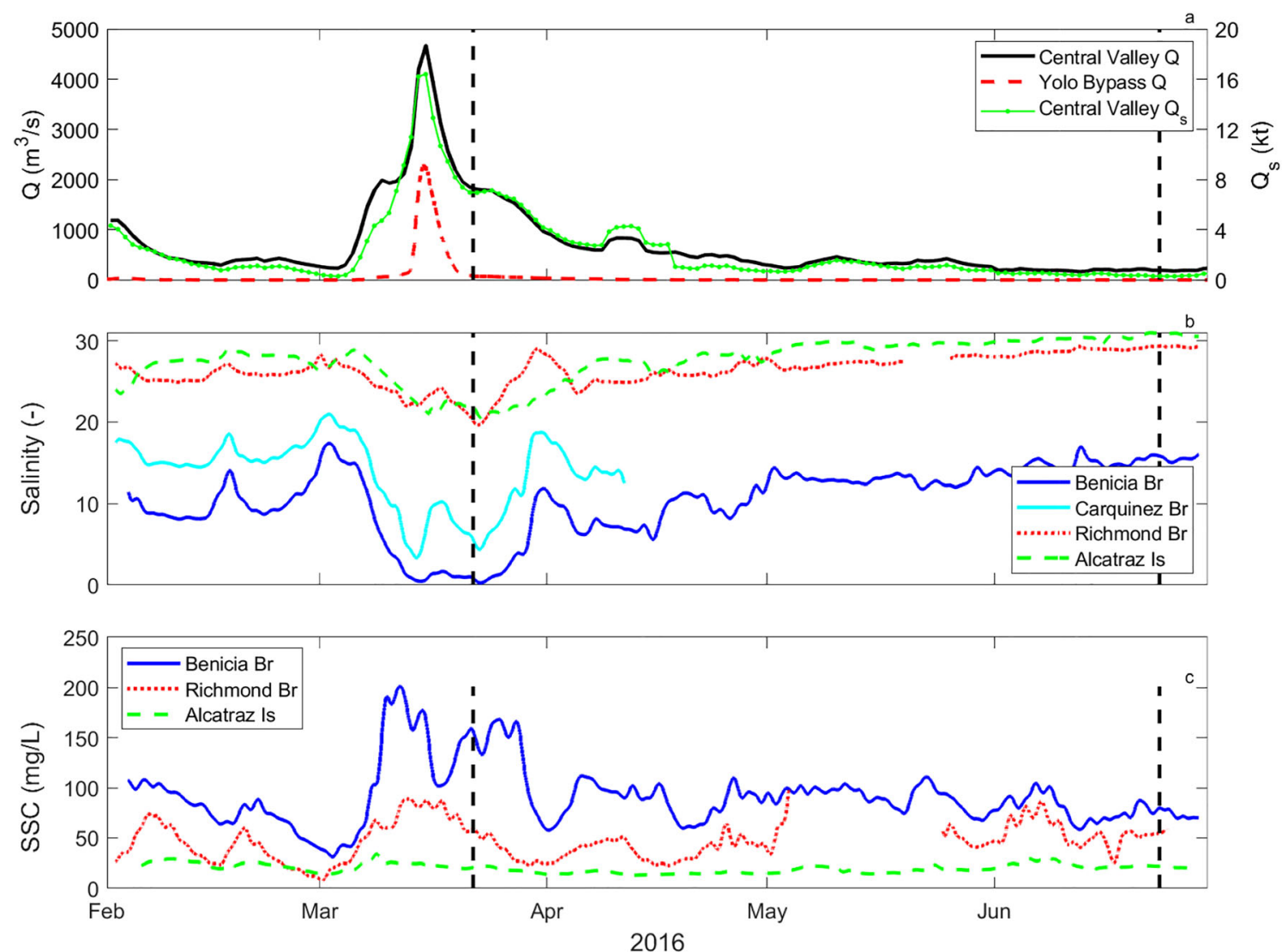

Fig. 3 Five-month time series in 2016 of a freshwater flow (Q, left $y$-axis) and suspended-sediment load $\left(\mathrm{Q}_{\mathrm{s}}\right.$, right $y$-axis) from Central Valley to San Francisco Estuary and flow into Yolo Bypass flood-control structure, and tidally filtered $\mathbf{b}$ salinity and $\mathbf{c}$ suspended-sediment concentration (SSC) at up-estuary locations. Near-bed sensor data shown for Benicia,
Carquinez (salinity data only), and Richmond stations; mid-depth sensor data shown for Alcatraz. Vertical dashed lines denote midpoint of highinflow (21 Mar 2016 23:05:30 Pacific Standard Time, PST) and lowinflow (23 Jun 2016 09:52:00 PST) field campaigns from the velocity vector data, water velocity at either end of the transect was flood-tide directed (into SFE; landward). This reversal in velocity direction across the transect was observed in many of the transects and indicates horizontal shear. This horizontal shear has been observed at this location previously (e.g., Erikson et al. 2013) and arises due to the inlet geometry.

One limitation of this study is the frequency of the $\mathrm{ADCP}$ - a higher-frequency instrument is better suited to observe SSC for the fine-grained sediments typically found in SFE (Wall et al. 2006). However, a lower-frequency instrument was required to measure water velocity over the deepest region of the transect. The lower frequency means lower sensitivity to the sediment in the water column, which introduces more uncertainty into the computed sediment fluxes. There is not a simple way around this problem, though, because even using two different instruments - one for water and one for sediment - would leave one with a dataset that does not span the full water column. Despite this limitation, the combination of an acoustic Doppler profiler with in situ sampling for suspended-sediment concentrations is an effective way to obtain data for quantification of sediment and water fluxes.

\section{Relation of Acoustic Backscatter to Suspended- Sediment Concentration}

While three calibration datasets of concurrent ABS and SSC were collected and related (Table 2), only two were used in this work. The point-integrating water sampler (P-61-A1) was deemed most suitable for this study; therefore, those two calibration curves were applied: one for 2016 measurements (March and June); and one for 2017 measurements (February). The regression parameters and statistics were similar for the March 2016 and June 2016 datasets (Table 2), and the June 2016 curve was taken as representative for all 2016 data. All regression models (Table 2) produced slopes (b1, Eqs. 1 and 2) that are positive as expected, and within the range of expected values based on previous studies (range 0.03-0.1, Landers et al. 2016). All bias-correction factors determined from model residuals were within the expected range of 1.01-1.1 (Rasmussen et al., 2009).

Laboratory analysis of water samples indicated fine-sized particles (diameter less than $63 \mu \mathrm{m}$ ) dominated all periods (Table 2). The average percent total mass as fine-sized particles, 

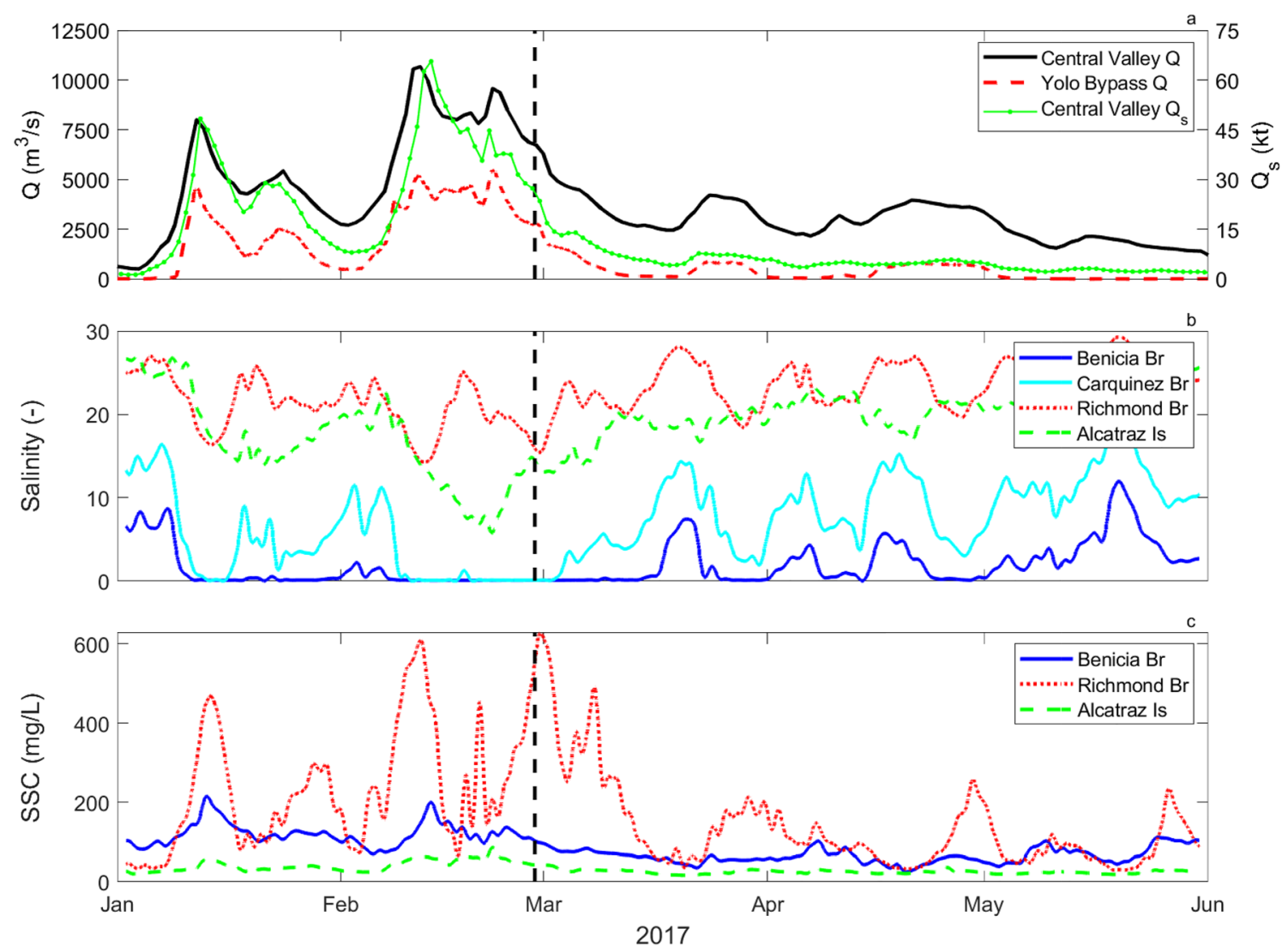

Fig. 4 A 5-month time series in 2017 of a freshwater flow (Q, left $y$-axis) and suspended-sediment load $\left(\mathrm{Q}_{\mathrm{s}}\right.$, right $y$-axis) from Central Valley to San Francisco Estuary and flow into Yolo Bypass flood-control structure, and tidally filtered $\mathbf{b}$ salinity and $\mathbf{c}$ suspended-sediment concentration
(SSC) at up-estuary locations. Near-bed sensor data shown for Benicia, Carquinez (salinity data only), and Richmond stations; mid-depth sensor data shown for Alcatraz. Vertical dashed line denotes midpoint of highinflow field campaign (27 Feb 2017 19:00:00 Pacific Standard Time) for each calibration dataset, was as follows: March 2016 - 90; June 2016-91; and February 2017-91 (Table 2).

An example of the spatial distribution of SSC (and ABS) derived from a processed (i.e., after any interpolation) transect is shown in Fig. 6, for the transect beginning 13:11 PST on 21 Mar 2016 (Appendix Table 5). For this transect, SSC was generally higher in the near-bed regions, and in the northern portion of the transect (elapsed distance $2.5-3.5 \mathrm{~km}$, Fig. 6).
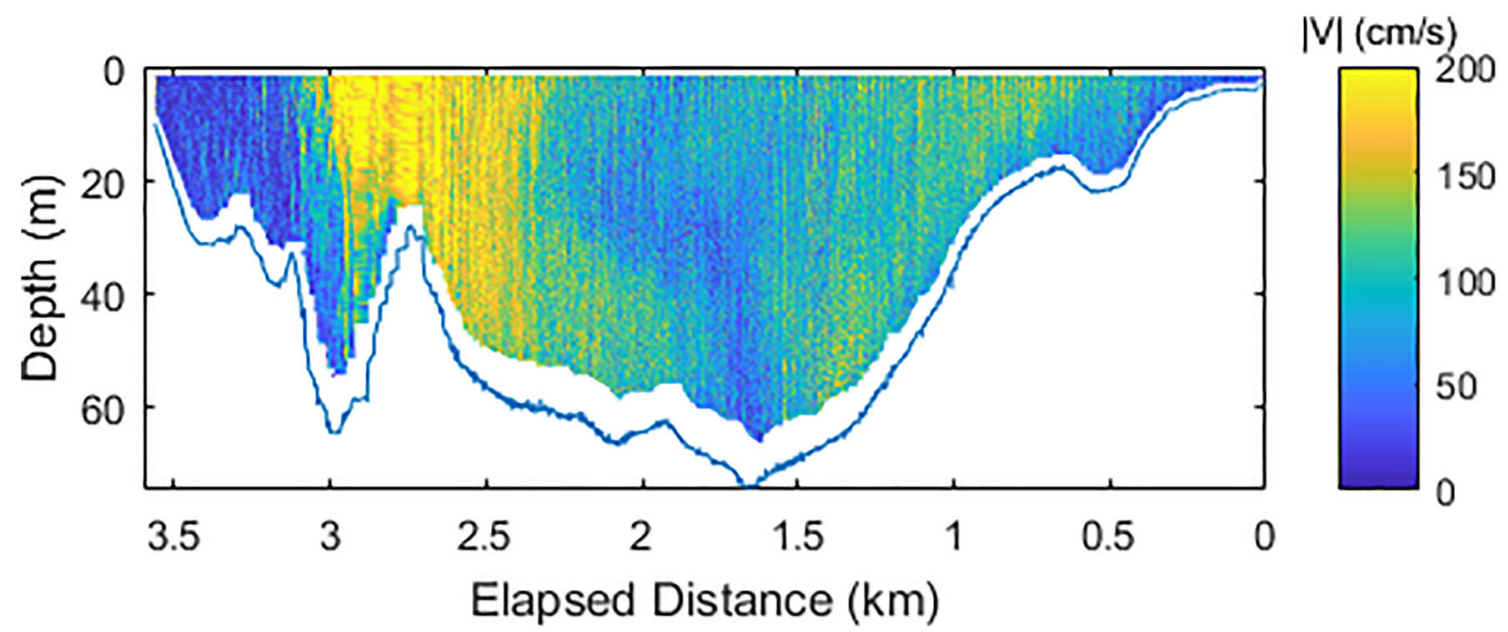

Fig. 5 Cross-sectional view of velocity magnitude $(|\mathrm{V}|)$ at the transect near the ocean boundary of SFE beginning 13:11 Pacific Standard Time on 21 Mar 2016 (Table 2). Left edge of plot corresponds to north end of transect. Maximum gap of $50 \mathrm{~m}$ used for interpolation 
Table 2 Sediment sampling methods, number of samples ( $n$ ), range and mean of percent fine-size particles (diameter less than $63 \mu \mathrm{m}$ ), calibration curve regression parameters (Eqs. 1 and 2), and coefficient of determination $\left(R^{2}\right)$ for each calibration dataset from the 2016 and 2017 field campaigns. $b_{0}$ : y-intercept; $b_{1}$ : slope; BCF: bias-correction factor. The June 2016 regression was used for all 2016 data; the March 2016 regression model was not applied in this study and is shown for comparison purposes only

\begin{tabular}{|c|c|c|c|c|c|c|c|c|}
\hline Date & Sampling method (sampler type) & $n$ & $\%$ fine range & $\%$ fine mean & $b_{0}$ & $b_{1}$ & $\mathrm{BCF}$ & $R^{2}$ \\
\hline Mar 2016 & Depth-integrated (D-96) & 19 & $79.7-95.1$ & 89.7 & -2.45 & 0.044 & 1.06 & 0.55 \\
\hline Jun 2016 & Point-integrated (P-61-A1) & 16 & $83.6-97.2$ & 90.6 & -2.68 & 0.048 & 1.02 & 0.91 \\
\hline Feb 2017 & Point-integrated (P-61-A1) & 19 & $48.1-100.0$ & 90.7 & -1.91 & 0.040 & 1.03 & 0.89 \\
\hline
\end{tabular}

The spatial distribution of sediment was generally heterogeneous at this cross-section.

\section{Calculated Flux of Water and Suspended Sediment at the Ocean Boundary}

Water flux, sediment flux, and transect-average SSC at the ocean boundary of SFE were computed for each valid transect (Appendix Tables 5, 6, 7). The time series of water flux and sediment flux for the February 2017 field campaign are presented in Fig. 7. Comparing observations on ebb and flood for each field campaign, peak water flux was on average $20 \%$ higher on ebb tide, while peak values of sediment flux and transect-average SSC were on average $20 \%$ and $25 \%$ higher on flood tide, respectively (Table 3 ). The lag between peak water flux and peak sediment flux or peak transect-average SSC varied from -1 to $+1.5 \mathrm{~h}$ (Table 3 ); resolution of the lag calculation is limited by transect duration (approximately $0.5 \mathrm{~h}$ ). Lags were in most cases small, with peak values of sediment flux and transect-average SSC typical- ly occurring within the first $0.5 \mathrm{~h}$ after peak water flow (negative lag, Table 3).

The 2017 field campaign (Fig. 7) had sufficient resolution and duration to allow for integration of observations over tidal phase to compare net fluxes between ebb and flood. Net volumetric flux of water at the oceanboundary transect was $19 \%$ greater on ebb tide $(2.0 \mathrm{e} 9$ $\mathrm{m}^{3}$ ) than on flood tide $\left(1.6 \mathrm{e} 9 \mathrm{~m}^{3}\right)$, explained by the volume of freshwater flow into the estuary (Fig. 4, Table 1) giving rise to longer duration (ebb: $6.5 \mathrm{~h}$; flood: $6.0 \mathrm{~h}$ ) and greater peak water flux magnitude of ebb tide (Table 3). However, net mass of suspended-sediment transported through the cross-section of the transect, computed by integrating suspended-sediment flux over the ebb and flood phases of the tide separately, was $20 \%$ greater on flood tide (7.0e4 metric tons) than on ebb tide (5.5e4 metric tons). Despite the longer duration and greater peak water discharge of the ebb tide, giving rise to net seaward export of water, more sediment was transported landward on the flood tide, in part due to greater SSC throughout the water column on the flood tide.

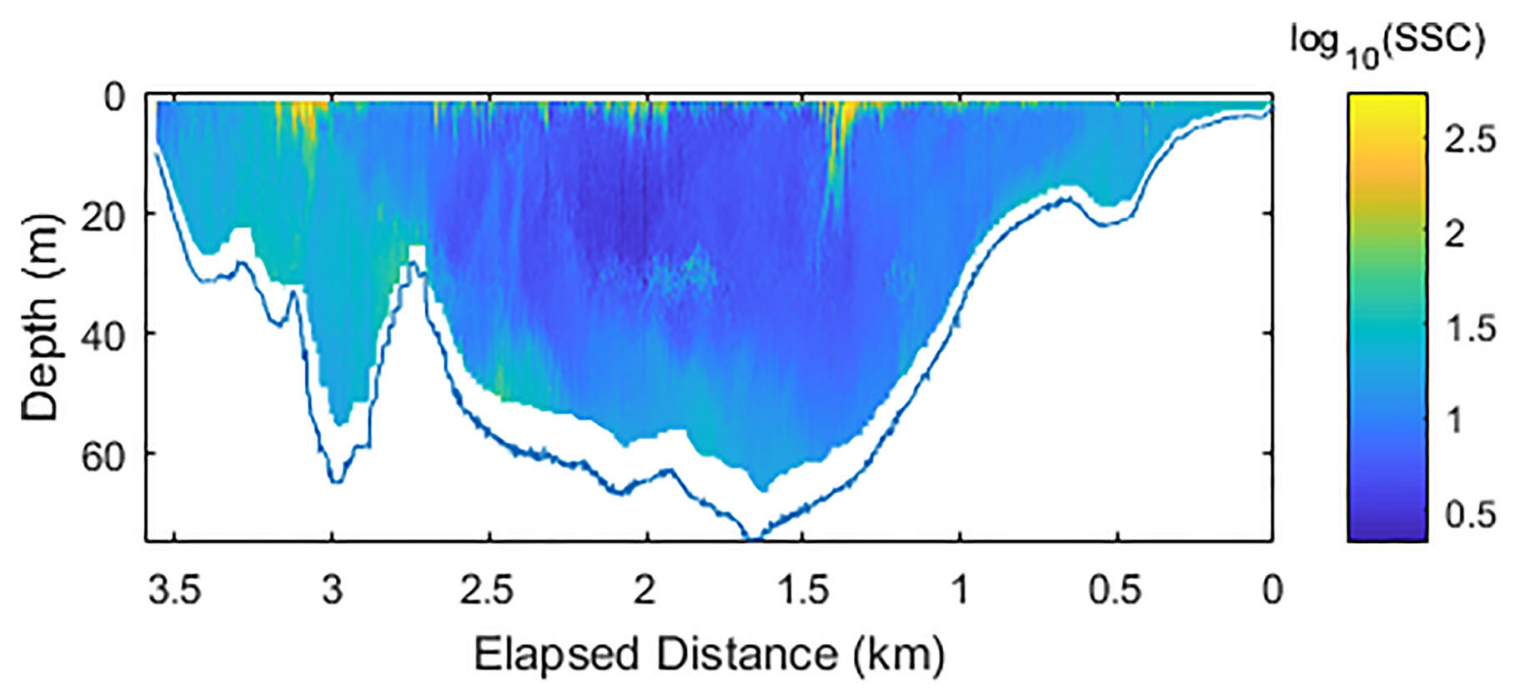

Fig. 6 Cross-sectional view of log-transformed suspended-sediment concentration (SSC, $\mathrm{mg} / \mathrm{L}$ ), computed from observed sediment-corrected acoustic backscatter via regression model (Table 2). Data shown are from the transect near the ocean boundary of SFE beginning 13:11 Pacific Standard Time on 21 Mar 2016 (as in Fig. 5). Left edge of plot corresponds to north end of transect 
Table 3 Peak values of water flux, sediment flux, and transect-average suspended-sediment concentration (SSC), by tidal phase (ebb and flood), for each field campaign. Positive flux indicates seaward transport; negative flux indicates landward transport. $\varphi$ is the phase lag relative to peak water flux (positive $\varphi$ : water flux lags; negative $\varphi$ : water flux leads), with resolution $\sim 0.5 \mathrm{~h}$

\begin{tabular}{|c|c|c|c|c|c|c|c|c|c|c|}
\hline \multirow[t]{2}{*}{ Date } & \multicolumn{2}{|c|}{ Peak water flux $\left(\mathrm{m}^{3} / \mathrm{s}\right)$} & \multicolumn{4}{|c|}{ Peak sediment flux (kg/min) } & \multicolumn{4}{|c|}{ Peak transect-average SSC $(\mathrm{mg} / \mathrm{L})$} \\
\hline & Ebb & Flood & Ebb & $\varphi(\mathrm{h})$ & Flood & $\varphi(\mathrm{h})$ & Ebb & $\varphi(\mathrm{h})$ & Flood & $\varphi(\mathrm{h})$ \\
\hline Mar 2016 & $1.3 \mathrm{e} 5$ & $-1.0 \mathrm{e} 5$ & $1.6 \mathrm{e} 5$ & -0.5 & $-2.0 \mathrm{e} 5$ & 0.0 & 25 & -0.5 & 33 & -0.5 \\
\hline Jun 2016 & $1.1 \mathrm{e} 5$ & $-0.9 \mathrm{e} 5$ & $1.2 \mathrm{e} 5$ & 0.0 & $-1.3 \mathrm{e} 5$ & 0.5 & 21 & 0.0 & 35 & -0.5 \\
\hline Feb 2017 & $1.3 \mathrm{e} 5$ & $-1.1 \mathrm{e} 5$ & $3.0 \mathrm{e} 5$ & 1.5 & $-4.6 \mathrm{e} 5$ & -1.0 & 62 & 0.0 & 68 & -1.0 \\
\hline
\end{tabular}

\section{Shear-Induced Resuspension of Sediment at the Ocean Boundary}

Pronounced tidal asymmetries in transect-averaged velocity shear $(V|V|)$ and its relation to SSC were observed for all field campaigns (Fig. 8). For all campaigns, maximum velocity shear observed on ebb tide exceeded that observed on flood tide, but SSC was generally lower on ebb tides and maximum SSC was concurrent with maximum flood-tide velocity shear (Fig. 8a). For flood tides during all field campaigns, as velocity shear increases, SSC increases linearly, although the regression is not statistically significant for the June 2016 field campaign (Fig. 8b). For ebb tides during the March 2016 and February 2017 field campaigns, the data collected during early ebb (defined as the first $2 \mathrm{~h}$ following slack after flood, indicated by asterisk symbols in Fig. 8) show little increase in SSC despite the increase in velocity shear to near-maximum ebb-tide values (Fig. 8a). As the ebb continues, SSC increases for the same value of velocity shear. June 2016 data are excluded from this discussion because the data were not collected during early ebb. Linear regression models of the flood-tide

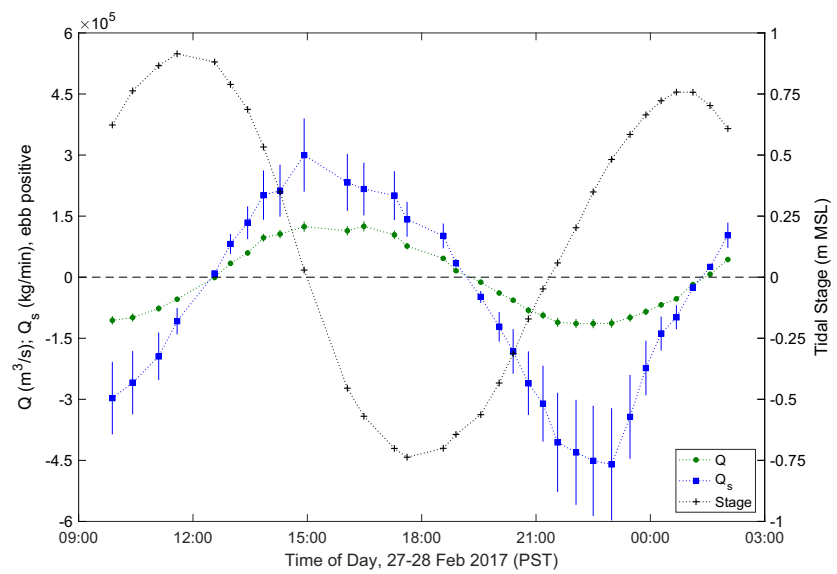

Fig. 7 Time series (in Pacific Standard Time, PST) of observations of water flux $(\mathrm{Q})$, suspended-sediment flux $\left(\mathrm{Q}_{\mathrm{s}}\right)$, and tidal stage (relative to mean sea level, MSL) at the ocean boundary of SFE during the February 2017 field campaign. Positive flux values indicate ebb-directed (seaward) transport. Observed tidal stage data from NOAA station 9414290 (San Francisco, CA). Error bars indicate 10\% and 30\% uncertainty in measurements of $\mathrm{Q}$ and $\mathrm{Q}_{\mathrm{s}}$, respectively data for the three field campaigns show similar slopes and varying y-intercepts (Fig. 8b). If shear-induced resuspension was tidally symmetric, the relation for ebb tide would have the same slope as for flood tide with opposite sign and same yintercept (shown as best-fit lines mirrored across the $x$-axis, Fig. 8b). For each field campaign, observed ebb SSC values are generally less than as predicted from the flood-tide data, indicating that shear-induced resuspension of sediment is tidally asymmetric and greater on flood tides.

\section{Watershed Inflow of Freshwater and Sediment}

Comparing the average volume of freshwater inflow and mass of sediment delivered to SFE from the Central Valley watershed over the water year preceding each field campaign, the storms prior to the 2017 field campaign delivered 4.5 and 6.2 times more water and sediment, respectively, than those prior to the 2016 field campaign (Table 4). During 2016, sediment inflow and outflow for the Suisun Bay subembayment (Fig. 1) were nearly equal (Table 4), indicating no net change in storage (i.e., deposition or erosion). In contrast, during 2017, the sediment inflow to Suisun Bay was almost five times lower than the outflow, indicating the subembayment had relatively high net erosion for the water year preceding the field campaign (Table 4).

The greater freshwater inflow in 2017 gave rise to stronger vertical salinity gradients at stations further down estuary (Carquinez Bridge and Richmond Bridge) compared to 2016 (Fig. 9). During peak watershed outflow in 2017, the vertical salinity gradient was $0 \mathrm{~m}^{-1}$ at Carquinez Bridge and reached a peak of $-2.3 \mathrm{~m}^{-1}$ on $18 \mathrm{Feb} 2017$ at Richmond Bridge (Fig. 9b).

\section{Discussion}

Our results indicate that suspended-sediment flux at the ocean boundary is tidally asymmetric, and that discharge from the Central Valley watershed both delivers sediment to the estuary and gives rise to physical processes that trap those sediments within the estuary. 
Fig. 8 Suspended-sediment concentration (SSC) as a function of shear-induced sediment resuspension surrogate $V|V|$ for a unique field days, with first and last transects of the day indicated and connecting lines indicating sequential measurements. SSC and velocity $(V)$ are transectaveraged quantities, with positive values of $V$ indicating ebb tide. Early-ebb data are indicated by asterisk $(*)$ and are defined as measurements collected during the first $2 \mathrm{~h}$ after slack after flood. b Best-fit lines for flood-tide data $(V|V|<0)$ from the three field campaigns with fitting parameters and statistics. Best-fit lines are mirrored across the $x$-axis $(V|V|=$ 0 ) line to highlight the assumption of tidal symmetry in shearinduced sediment resuspension. Nearly all ebb-tide SSC values for each field campaign are less than those predicted from flood-tide observations, indicating tidal symmetry is not present in these data

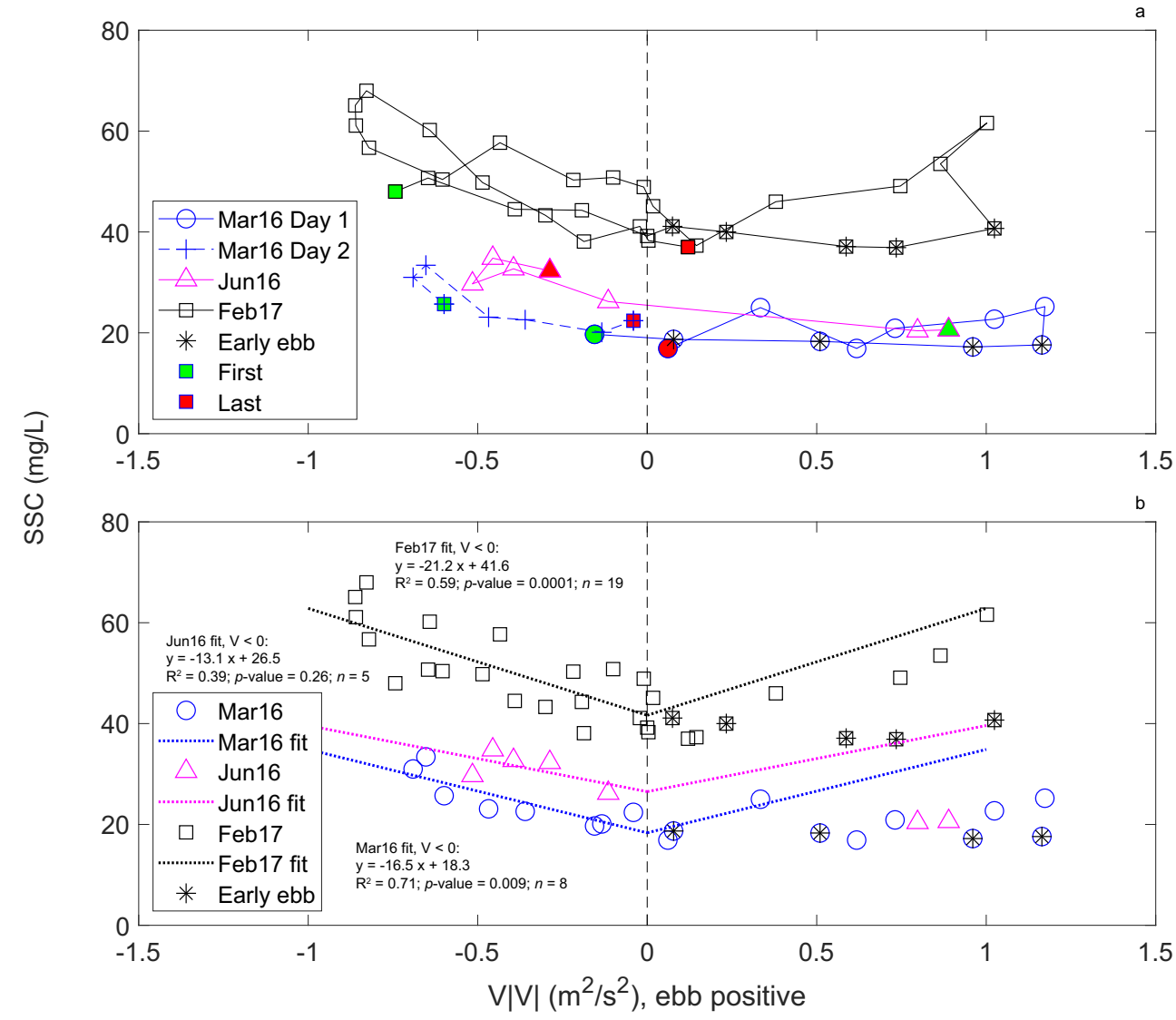

\section{Comparison of 2016 and 2017 Field Campaigns}

During this study, an opportunity arose to conduct field observations of suspended-sediment flux at the estuary-ocean boundary following major watershed runoff in 2016 and again in 2017, as well as during dry-season conditions. Central Valley watershed discharge during 2016 was generally lower than the long-term mean, except for the March 2016 storm (Fig. 2). In contrast, Central Valley watershed discharge during 2017 was generally higher than the long-term mean, with an annual peak nearly three times larger than that for 2016 (Fig. 2). Despite the higher inflows in 2017, peak observed water flux at the Golden Gate transect

Table 4 Daily averaged values for water volume and sediment mass load inputs into San Francisco Estuary (from Central Valley), net seaward sediment mass load at Benicia Bridge, and deposition for one up-estuary subembayment (Suisun Bay) for the water year (WY) preceding sampling for each field campaign. Daily averaged values computed as the sum over was equal for March 2016 and February 2017 campaigns (Table 3), demonstrating that tidal forcing dominates the discharge signal at the estuary-ocean boundary of SFE. The peak inflow from the Delta that was observed in WY2016 $\left(4100 \mathrm{~m}^{3} / \mathrm{s}\right.$, Figs. 2 and 3a) is only $3 \%$ of the observed peak measured outflow at the Golden Gate $\left(1.3 \mathrm{e} 5 \mathrm{~m}^{3} / \mathrm{s}\right.$, Table 3$)$ during the March 2016 measurement campaign. The tidal prism of SFE causes tidal exchange of water in a volume that far exceeds the freshwater contribution from the watershed.

Observed suspended-sediment flux at the estuary-ocean boundary of SFE following the peak watershed outflow in 2017 was substantially larger in magnitude across the range

the WY preceding sampling divided by total number of days. Deposition computed as difference between loads at Central Valley watershed boundary and Benicia Bridge (Fig. 1). Negative values of deposition indicate net erosion

\begin{tabular}{llllll}
\hline Sampling date & $\begin{array}{l}\text { Central Valley runoff } \\
\left(\mathrm{km}^{3} / \mathrm{d}\right)\end{array}$ & $\begin{array}{l}\text { Central Valley load } \\
(\mathrm{kt} / \mathrm{d})\end{array}$ & Benicia Br load $(\mathrm{kt} / \mathrm{d})$ & $\begin{array}{l}\text { Suisun Bay deposition } \\
(\mathrm{kt} / \mathrm{d})\end{array}$ & No. days preceding in WY \\
\hline 21-22 Mar 2016 & 0.048 & 1.7 & 3.2 & -1.5 & 173 \\
23 Jun 2016 & 0.047 & 1.8 & 1.0 & 0.7 & 267 \\
27 Feb 2017 & 0.22 & 10.6 & 50.1 & -39.5 & 150 \\
\hline
\end{tabular}



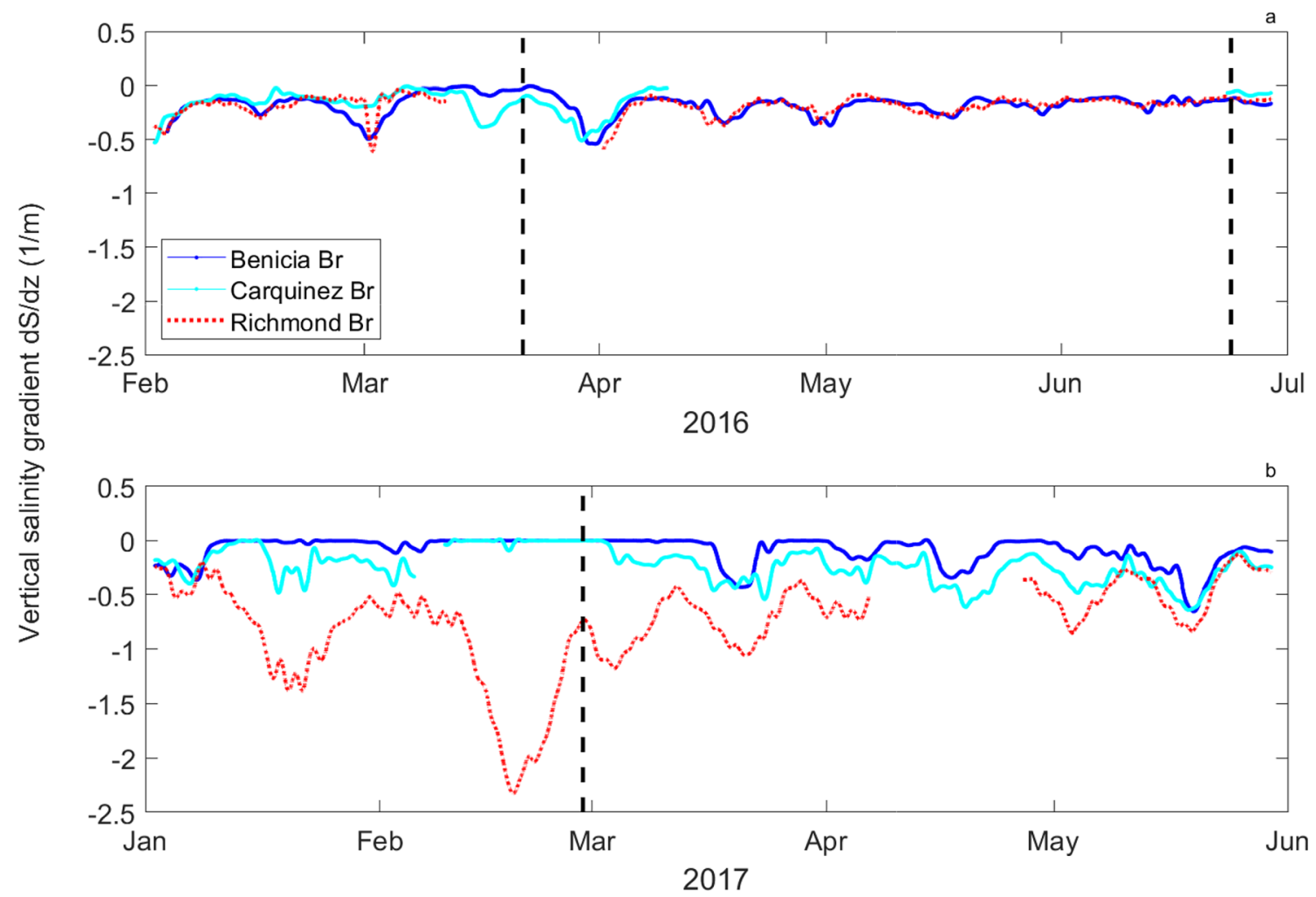

Fig. 9 Five-month time series of tidally filtered vertical salinity gradient at three locations in the estuary upstream of the ocean boundary for a 2016 and b 2017. Gradient computed as difference between tidally filtered salinity divided by the vertical distance between the sensors (near-bed minus mid-depth). Vertical dashed lines denote midpoint of field campaigns: 2016 high inflow (21 Mar 2016 23:05:30 Pacific Standard Time, PST); 2016 low inflow (23 Jun 2016 09:52:00 PST); and 2017 high inflow (27 Feb 2017 19:00:00 PST) of observed water fluxes than that for 2016. Comparison of suspended-sediment flux $\left(Q_{s}\right)$ versus water flux $(Q)$ for this study and Erikson et al. (2013) demonstrates a similar relationship for the March 2016 and June 2016 datasets on ebb and flood tides (Fig. 10). On flood tides, the March 2016, June 2016, and Erikson et al. (2013) datasets appear visually similar with shallower slope for a line fit through the data. In contrast, flood-tide data from February 2017 appear as a unique population, with a steeper slope for a line fit through the data (Fig. 10). For ebb tides, data from February 2017 and those reported by Erikson et al. (2013) appear as a similar population different from the two 2016 datasets, with a
Fig. 10 Scatter plot of suspendedsediment flux $\left(\mathrm{Q}_{\mathrm{s}}, y\right.$-axis) versus water flux $(\mathrm{Q}, x$-axis) for this study (Mar 2016, Jun 2016, and Feb 2017 field campaigns plotted separately) and a previous study (Erikson et al. 2013). Values of Q and $\mathrm{Q}_{\mathrm{s}}$ were divided by 1000 to simplify axes labels. Positive values of flux indicate ebbdirected transport (out of San Francisco Estuary). Error bars indicate $10 \%$ and $30 \%$ uncertainty in measurements of $\mathrm{Q}$ and $\mathrm{Q}_{\mathrm{s}}$, respectively

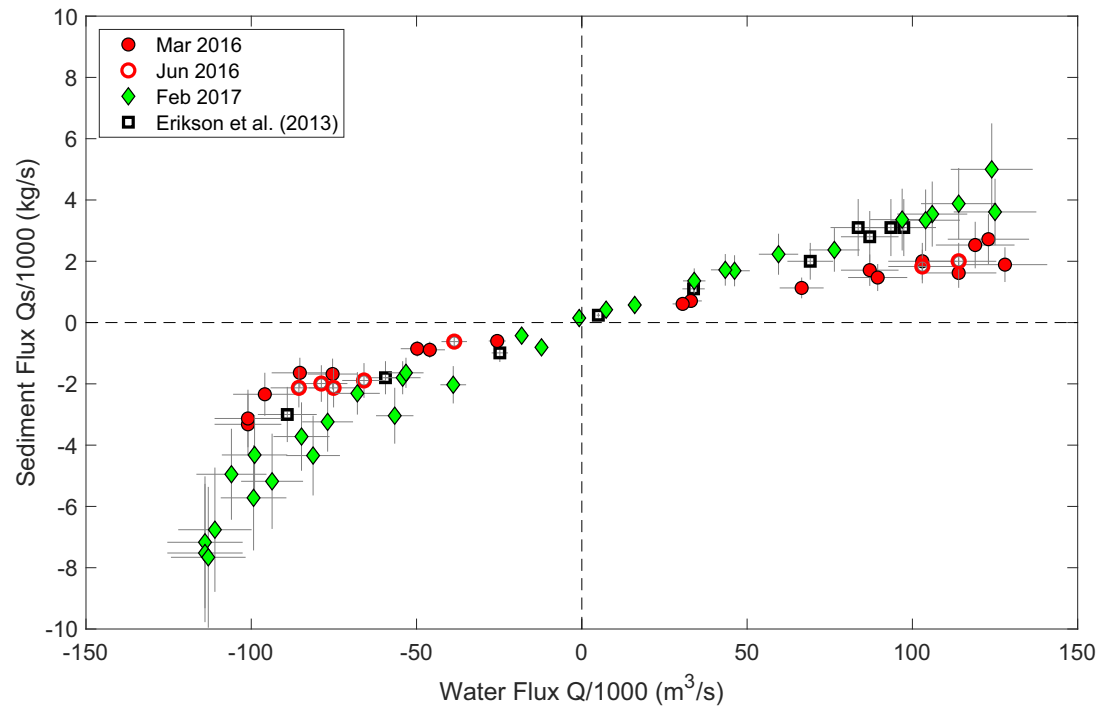


steeper slope for a line fit through the data. Assuming local hydrodynamics were relatively consistent between field campaigns and dominated by tidal forcing, steeper slopes in these relationships should be an indication of the higher average SSC near the ocean boundary during these measurement periods.

\section{Tidally Asymmetric Suspended-Sediment Flux}

Our tidal-cycle observations following storm events in two years and during one dry season showed higher suspended-sediment flux on flood tides than on ebb tides, which was unexpected considering the large inflows of freshwater and sediment from the Central Valley and the general estuary characteristic of conveying water and suspended material from watershed to ocean. The tidal asymmetry in transect-average SSC, with greater SSC on flood tides, gives rise to the flood-dominant sediment flux observed during this study. Here we further explore available data and offer a few explanations that may have given rise to these observations.

A first potential explanation for flood-dominant suspended-sediment flux is the presence of an erodible sediment pool seaward of the ocean boundary. Our data demonstrated tidal asymmetry in shear-induced resuspension of sediment, with ebb tides exhibiting very-low SSC in response to increasing velocity shear during the first $2 \mathrm{~h}$ of ebb (Fig. 8). If sediment transport in SFE is supply limited as expected (Schoellhamer 2011), a larger pool of erodible sediment seaward of the Golden Gate could explain why SSC is greater on flood tide. For flood tides, an increase in shear produces nearly the same change in SSC for both dry and wet conditions (comparing slope of lines in Fig. 8a), particularly for the two campaigns in 2016, which is a comparison of wet and dry conditions in a relatively short period, and suggests no substantial change in the size of the bed deposit between wet and dry conditions. The storms in 2017 delivered more sediment to the estuary (Table 4), more of which remained in suspension and was transported to the ocean boundary, giving rise to higher ambient SSC in the system during the field observations (Table 1; Fig. 8b; Fig. 10). The steeper slope evident in 2017 flood-tide data for the shear-versus-SSC relation (Fig. 8b) suggests possibly more deposition outside the Golden Gate and further supports the supplylimited condition. If erosion were supply limited, there would be more erosion per unit velocity, which is evident from the steeper slope for flood-tide data in 2017 (Fig. $8 b)$.

A second potential explanation for the lower magnitude of ebb-directed sediment flux is that greater SSC was present outside the Golden Gate. This situation could arise due to (1) concurrent sediment delivery from coastal tributaries, increasing ambient SSC outside the estuary, or (2) for the case where our field campaigns were conducted after the passing of the peak of the watershed-sourced sediment plume through the estuary and into the Pacific Ocean. For (1), if this was the case, we would expect to see some tidal symmetry in SSC from late flood to early ebb, which is not evident in the March 2016 nor February 2017 field campaigns (Fig. 8a). For (2), if the peak SSC from the watershed plume had already passed through the Golden Gate, there would be higher SSC outside the Gate which could cause a negative (landward) concentration gradient in suspended sediment. As will be further described in the next section, review of SSC data at the up-estuary station nearest the ocean boundary (Alcatraz Island, Figs. 3c and 4c) does indicate that peak SSC at this station was prior to the March 2016 and February 2017 field campaigns. However, this explanation is not supported by results from the dry season in June 2016, since there was no recent watershed plume, and further suggests there was an erodible pool of sediment located just outside the estuary that was resuspended during flood tides.

Our observations demonstrated substantial heterogeneity in the distribution of SSC in the cross-section at the ocean boundary and temporally varying vertical gradients in salinity in up-estuary locations. These findings suggest that remote sensing technology, which at present can provide information about only the uppermost layer of water, should be applied with caution for deep-water locations of the estuary.

\section{Trapping of Watershed Sediment Pulses in SFE}

For both wet-season field campaigns (March 2016 and February 2017), we hypothesize that substantial trapping of watershed-sourced pulses of sediment occurred within SFE, specifically San Pablo Bay (Fig. 1). Monitoring stations in the estuary indicated the movement and apparent trapping of a sediment pulse following the March 2016 storm: elevated SSC was observed following Central Valley discharge at Benicia Bridge with a smaller peak observed passing out of San Pablo Bay at Richmond Bridge; but SSC near the estuary-ocean boundary at Alcatraz Island exhibited very little change (Fig. 3), suggesting limited watershed sediment outflow at the Golden Gate following the March 2016 storm. Although the focus of this paper was on flux of sediment suspended in the water column, one limitation of this study is the lack of data collected to understand bedload transport of sediment, which is known to be net ebb-directed at this location (Barnard et al. 2013).

The observed relatively low SSC at the ocean boundary during the March 2016 campaign could be explained by 
too much lag between the Central Valley discharge peak and the campaign (thus missing the peak SSC of the freshwater plume). Inspection of the tidally filtered SSC at Alcatraz Island (Fig. 3c), however, shows that although the tidally filtered SSC peak occurred earlier than the field campaign, tidally filtered peak values during June 2016 were only slightly lower. Taken with the low value of suspendedsediment load from the Central Valley (Fig. 3a), these results suggest that there was not a large amount of down-estuary sediment export following the 2016 storms. In contrast, the peak observed transect-averaged SSC at the Golden Gate during February 2017 sampling was double that observed in the previous two field trips (Table 1). Comparing transect data to Alcatraz shows again that the tidally filtered SSC peak $(86 \mathrm{mg} /$ $\mathrm{L}$ on $21 \mathrm{Feb} 2017$ ) occurred earlier than the field campaign (68 $\mathrm{mg} / \mathrm{L}$ on $27 \mathrm{Feb} 2017$ ); however, tidally filtered SSC decreased to a summer baseline in 2017 similar to that in 2016 .

During 2017, suspended-sediment load from the Central Valley had a peak value that was about four times larger than that observed in 2016 (2016: 16 kt, 2017: 65 kt; Figs. 3a and $4 a)$; when considering the daily averaged cumulative sediment load, storms in 2017 delivered six times more sediment than those in 2016 (Table 4). However, the question remains as to why we did not observe ebb-dominated suspended-sediment flux at the ocean boundary. A striking difference between 2016 and 2017 is seen in tidally filtered SSC at Richmond Bridge. During 2016, tidally filtered SSC at the Richmond Bridge near-bed sensor was at an intermediate value between Benicia Bridge upstream and Alcatraz Island downstream (Fig. 3c). However, during 2017, tidally filtered SSC at the near-bed sensor at Richmond reached peak values of $600 \mathrm{mg} / \mathrm{L}$, three times greater than that observed at Benicia Bridge (Fig. 4c) and about six times greater than that observed at Richmond Bridge during 2016 (Fig. 3c). Comparison of tidally filtered salinity at SFE stations between 2016 and 2017 shows the presence of stratified conditions at Richmond Bridge for several weeks during early 2017 and especially the latter half of February 2017 (Fig. 9). During 2016, tidally filtered salinity at Richmond Bridge near-bed sensor was similar to that at Alcatraz Island mid-depth sensor with minimum values of about 20 (Fig. 5b), whereas during 2017 salinity at Richmond deviated from that at Alcatraz Island by increasing from 15 to 25 in early February after a large freshwater pulse entered San Pablo Bay (Fig. 4b).

The increase in salinity at Richmond Bridge near the bed, relative to Alcatraz Island at mid-depth, is indicative of vertical density stratification causing near-surface seaward flow and near-bed landward flow, induced by the longitudinal density gradient set up by freshwater inflow. Comparison of tidally filtered SSC to tidally filtered salinity near the bed at Richmond Bridge during Jan-Mar 2017 shows peaks in SSC are concurrent with minima in salinity (Fig. 4b), events that occur during spring tides. During spring tides, tidal excursion is higher and tidal mixing is greater, so this observation can be explained by either (1) the seaward movement of an estuarine turbidity maximum (ETM) located north of Richmond Bridge in San Pablo Bay or (2) the breakdown of vertical density stratification that set up during the previous neap tides. An ETM is a longitudinal maximum of SSC, and can form by several mechanisms including gravitational circulation or tidal asymmetry of velocity and SSC; ETMs require a varying salinity field but are not associated with one particular salinity (Jay and Musiak 1994; Schoellhamer 2001). In SFE, an ETM is present and usually located in Suisun Bay (Schoellhamer 2001). During 2016, Central Valley inflow was generally below average until the event in March 2016 (Fig. 2), and net sediment export from Suisun Bay was small (Table 4); these lines of evidence suggest that the ETM likely remained in Suisun Bay and sediments were trapped within Suisun Bay. During 2017, the extreme freshwater discharge from the Central Valley appeared to force the ETM downstream into San Pablo Bay (Figs. 4a-b, 9b), which would cause trapping of sediment (Jay and Musiak 1994) in San Pablo Bay.

Destruction of the vertical stratification formed during neap tides would enhance both vertical mixing and resuspension from the bed; greater vertical mixing causes fresher nearsurface waters to mix with saltier near-bed waters, producing lower values of near-bottom salinity on spring tide compared to neap tide. Without vertical stratification, turbulent mixing is greater, which causes increased resuspension of sediment from the bed, increasing SSC on spring tides compared to stratified conditions on neap tides. Because the subtidal or residual velocity is landward near the bed in an estuary (Geyer and MacCready 2014) and SSC was high near the bed during spring tides in San Pablo Bay (Fig. 4c), net landward transport of sediment likely occurred in this region of the estuary. Taken in context with the relatively low ebb-directed sediment flux values at the ocean boundary (Table 3, Fig. 10), these explanations are consistent with the hypothesis that Central Valley watershed sediment discharge is trapped within the upper estuary following freshwater runoff.

One limitation related to this discussion of sediment trapping is the temporal scope of the dataset. The results provide good vertical resolution through portions of the tidal cycle, but computation of net fluxes requires measurements over longer periods of time. Presently, there is no technique available that can observe velocities and suspended sediments throughout a deep channel cross-section without humans physically on-site. The acoustic approach employed here provides high resolution and relatively rapid measurement capability.

\section{Conclusions}

The use of a down-looking acoustic Doppler current profiler to measure unsteady flows of both water and sediment at the 
ocean-estuary boundary yields data with unprecedented spatial resolution that cannot currently be obtained by any other technique. Here the focus was on transect-averaged quantities, but spatial variations within each transect are also evident and can be used to verify modeling results or hypotheses about flow structures at the ocean boundary. The methodology relies on empirical relationships between sediment-corrected acoustic backscatter and suspended-sediment concentration and is rapid enough to yield nearly synoptic results for a crosssection on the order of $1 \mathrm{~km}$ in width by $60 \mathrm{~m}$ maximum depth. When considered in conjunction with monitoring data and existing models of sediment flux at up-estuary locations, a broader perspective of sediment transport and trapping within the estuary is obtained, which provides evidence of the development of estuarine turbidity maxima in response to large freshwater inflows. We highlight the following conclusions:

1) The dataset described here fortuitously includes two extremes of northern California's recent hydrological cycle, with the last year of a drought in 2016, and the recordhigh precipitation year of 2017.

2) Central Valley watershed discharge is generally at least one order of magnitude less than peak tidal flows through the Golden Gate.

3) Tidal asymmetry in SSC at the ocean boundary, with lower SSC on ebb tides compared to flood tides, is thought to be the cause of observed flood-dominant suspended-sediment flux and may arise due to a larger erodible pool of sediment located outside the ocean boundary.

4) Large freshwater inflows to the estuary can increase the ambient value of SSC; transect-averaged values of SSC varied by a factor of two between the three measurement campaigns. These large flows also modify longitudinal density gradients and hydrodynamics and lead to the development of estuarine turbidity maxima at different locations in the estuary, which are hypothesized to cause substantial sediment trapping in the estuary.

\section{Appendix}

Table 5 March 2016 ADCP transects: date (format: month/day/year); start and end times of each transect (time zone: Pacific Standard Time, PST); observed tidal stage (datum: mean sea level, MSL) at San Francisco, CA (station 9414290); computed volumetric water flux; computed suspended-sediment flux; and mean suspended-sediment concentration (SSC) for the transect. Positive flux indicates ebb-tide directed transport (toward ocean boundary; seaward); negative flux indicates flood-tide directed transport (from ocean boundary; landward)

\begin{tabular}{|c|c|c|c|c|c|c|c|}
\hline Date & $\begin{array}{l}\text { Start time } \\
\text { (PST) }\end{array}$ & $\begin{array}{l}\text { End time } \\
\text { (PST) }\end{array}$ & $\begin{array}{l}\text { Tidal stage (m } \\
\text { MSL) }\end{array}$ & $\begin{array}{l}\text { Water flux }\left(\mathrm{m}^{3} /\right. \\
\mathrm{s})\end{array}$ & $\begin{array}{l}\text { Sediment flux (kg/ } \\
\mathrm{s})\end{array}$ & $\begin{array}{l}\text { Sediment flux (kg/ } \\
\text { min) }\end{array}$ & $\begin{array}{l}\text { Transect-average SSC } \\
(\mathrm{mg} / \mathrm{L})\end{array}$ \\
\hline $3 / 21 / 16$ & $10: 22$ & $10: 50$ & 0.86 & $-49,800$ & -853 & $-51,200$ & 19.7 \\
\hline $3 / 21 / 16$ & $11: 33$ & $12: 12$ & 0.69 & 33,000 & 706 & 42,400 & 18.7 \\
\hline $3 / 21 / 16$ & $12: 37$ & 13:04 & 0.37 & 87,100 & 1710 & 103,000 & 18.3 \\
\hline $3 / 21 / 16$ & $13: 11$ & $13: 39$ & 0.11 & 114,000 & 1620 & 97,200 & 17.2 \\
\hline $3 / 21 / 16$ & $13: 43$ & $14: 13$ & -0.13 & 128,000 & 1890 & 113,000 & 17.6 \\
\hline $3 / 21 / 16$ & $14: 17$ & $14: 43$ & -0.32 & 123,000 & 2720 & 163,000 & 25.2 \\
\hline $3 / 21 / 16$ & $14: 50$ & $15: 18$ & -0.50 & 119,000 & 2530 & 152,000 & 22.7 \\
\hline $3 / 21 / 16$ & $15: 19$ & $15: 45$ & -0.60 & 103,000 & 2000 & 120,000 & 20.9 \\
\hline $3 / 21 / 16$ & $15: 52$ & $16: 17$ & -0.67 & 89,500 & 1470 & 88,200 & 16.9 \\
\hline $3 / 21 / 16$ & $16: 18$ & $16: 45$ & -0.70 & 66,500 & 1130 & 67,800 & 25.0 \\
\hline $3 / 21 / 16$ & $17: 07$ & $17: 33$ & -0.60 & 30,500 & 609 & 36,500 & 16.9 \\
\hline $3 / 22 / 16$ & $07: 49$ & $08: 36$ & 0.09 & $-95,900$ & -2340 & $-140,000$ & 25.7 \\
\hline $3 / 22 / 16$ & $08: 46$ & 09:18 & 0.35 & $-101,000$ & -3320 & $-199,000$ & 31.0 \\
\hline $3 / 22 / 16$ & 09:21 & 09:52 & 0.52 & $-101,000$ & -3130 & $-188,000$ & 33.4 \\
\hline $3 / 22 / 16$ & 09:53 & $10: 18$ & 0.61 & $-85,300$ & -1640 & $-98,400$ & 23.1 \\
\hline $3 / 22 / 16$ & $10: 21$ & $10: 51$ & 0.66 & $-75,400$ & -1680 & $-101,000$ & 22.6 \\
\hline $3 / 22 / 16$ & $10: 56$ & $11: 23$ & 0.70 & $-46,000$ & -889 & $-53,300$ & 20.1 \\
\hline $3 / 22 / 16$ & $11: 24$ & $11: 49$ & 0.66 & $-25,600$ & -601 & $-36,100$ & 22.4 \\
\hline
\end{tabular}


Table 6 June 2016 ADCP transects: date (format: month/day/year); start and end times of each transect (time zone: Pacific Standard Time, PST); observed tidal stage (datum: mean sea level, MSL) at San Francisco, CA (station 9414290); computed volumetric water flux; computed suspended-sediment flux; and mean suspended-sediment concentration (SSC) for the transect. Positive flux indicates ebb-tide directed transport (toward ocean boundary; seaward); negative flux indicates flood-tide directed transport (from ocean boundary; landward)

\begin{tabular}{lllllllll}
\hline Date & Start time (PST) & End time (PST) & $\begin{array}{l}\text { Tidal stage } \\
(\mathrm{m} \mathrm{MSL})\end{array}$ & Water flux $\left(\mathrm{m}^{3} / \mathrm{s}\right)$ & $\begin{array}{l}\text { Sediment flux } \\
(\mathrm{kg} / \mathrm{s})\end{array}$ & $\begin{array}{l}\text { Sediment flux } \\
(\mathrm{kg} / \mathrm{min})\end{array}$ & Transect-average SSC (mg/L) \\
\hline $6 / 23 / 16$ & $06: 27$ & $06: 47$ & -1.04 & 114,000 & 2000 & 120,000 & 20.6 \\
$6 / 23 / 16$ & $06: 48$ & $07: 12$ & -1.08 & 103,000 & 1830 & 109,800 & 20.4 & 26.2 \\
$6 / 23 / 16$ & $09: 22$ & $09: 45$ & -0.75 & $-38,600$ & -621 & $-37,260$ & 32.7 \\
$6 / 23 / 16$ & $10: 53$ & $11: 24$ & -0.25 & $-75,100$ & -2130 & $-127,800$ & 29.7 \\
$6 / 23 / 16$ & $11: 26$ & $11: 51$ & -0.07 & $-85,600$ & -2130 & $-127,800$ & 34.8 \\
$6 / 23 / 16$ & $11: 52$ & $12: 22$ & 0.10 & $-78,800$ & -1990 & $-119,400$ & 32.3 \\
$6 / 23 / 16$ & $12: 53$ & $13: 17$ & 0.36 & $-65,900$ & -1890 & $-113,400$ & 3 \\
\hline
\end{tabular}

Table 7 February 2017 ADCP transects: date (format: month/day/ year); start and end times of each transect (time zone: Pacific Standard Time, PST); observed tidal stage (datum: mean sea level, MSL) at San Francisco, CA (station 9414290); computed volumetric water flux; computed suspended-sediment flux; and mean suspended-sediment concentration (SSC) for the transect. Positive flux indicates ebb-tide directed transport (toward ocean boundary; seaward); negative flux indicates flood-tide directed transport (from ocean boundary; landward)

\begin{tabular}{|c|c|c|c|c|c|c|c|}
\hline Date & Start time (PST) & End time (PST) & $\begin{array}{l}\text { Tidal stage } \\
\text { (m MSL) }\end{array}$ & Water flux $\left(\mathrm{m}^{3} / \mathrm{s}\right)$ & Sediment flux $(\mathrm{kg} / \mathrm{s})$ & $\begin{array}{l}\text { Sediment flux } \\
(\mathrm{kg} / \mathrm{min})\end{array}$ & $\begin{array}{l}\text { Transect-average SSC } \\
(\mathrm{mg} / \mathrm{L})\end{array}$ \\
\hline $2 / 27 / 17$ & $9: 53$ & $10: 25$ & 0.63 & $-106,000$ & -4950 & $-297,000$ & 48.0 \\
\hline $2 / 27 / 17$ & $10: 25$ & $10: 54$ & 0.76 & $-99,000$ & -4320 & $-259,200$ & 50.7 \\
\hline $2 / 27 / 17$ & 11:06 & $11: 33$ & 0.87 & $-76,900$ & -3240 & $-194,400$ & 44.5 \\
\hline $2 / 27 / 17$ & $11: 35$ & $12: 00$ & 0.92 & $-54,200$ & -1800 & $-108,000$ & 44.3 \\
\hline $2 / 27 / 17$ & $12: 34$ & $12: 58$ & 0.85 & -793 & 148 & 8880 & 39.2 \\
\hline $2 / 27 / 17$ & $12: 59$ & $13: 26$ & 0.79 & 34,000 & 1360 & 81,600 & 41.1 \\
\hline $2 / 27 / 17$ & $13: 26$ & $13: 49$ & 0.68 & 59,500 & 2230 & 133,800 & 40.0 \\
\hline $2 / 27 / 17$ & $13: 51$ & $14: 15$ & 0.55 & 96,900 & 3360 & 201,600 & 37.1 \\
\hline $2 / 27 / 17$ & $14: 17$ & $14: 36$ & 0.34 & 106,000 & 3540 & 212,400 & 36.9 \\
\hline $2 / 27 / 17$ & $14: 55$ & $15: 27$ & 0.04 & 124,000 & 5000 & 300,000 & 40.7 \\
\hline $2 / 27 / 17$ & $16: 03$ & $16: 22$ & -0.45 & 114,000 & 3880 & 232,800 & 53.5 \\
\hline 2/27/17 & $16: 29$ & $16: 54$ & -0.57 & 125,000 & 3610 & 216,600 & 61.6 \\
\hline $2 / 27 / 17$ & $17: 17$ & $17: 36$ & -0.70 & 104,000 & 3340 & 200,400 & 49.1 \\
\hline $2 / 27 / 17$ & $17: 37$ & $18: 01$ & -0.74 & 76,400 & 2370 & 142,200 & 46.0 \\
\hline $2 / 27 / 17$ & $18: 34$ & $18: 53$ & -0.70 & 46,200 & 1690 & 101,400 & 37.3 \\
\hline $2 / 27 / 17$ & $18: 54$ & $19: 26$ & -0.64 & 16,000 & 574 & 34,440 & 45.1 \\
\hline $2 / 27 / 17$ & $19: 33$ & $20: 00$ & -0.56 & $-12,200$ & -809 & $-48,540$ & 48.9 \\
\hline $2 / 27 / 17$ & 20:02 & $20: 23$ & -0.44 & $-38,900$ & -2030 & $-121,800$ & 50.8 \\
\hline $2 / 27 / 17$ & $20: 24$ & $20: 47$ & -0.31 & $-56,600$ & -3040 & $-182,400$ & 50.3 \\
\hline $2 / 27 / 17$ & $20: 48$ & $21: 10$ & -0.17 & $-81,300$ & -4340 & $-260,400$ & 57.7 \\
\hline $2 / 27 / 17$ & $21: 11$ & $21: 33$ & -0.05 & $-93,700$ & -5180 & $-310,800$ & 50.4 \\
\hline 2/27/17 & $21: 34$ & 22:01 & 0.06 & $-111,000$ & -6760 & $-405,600$ & 56.7 \\
\hline $2 / 27 / 17$ & $22: 03$ & $22: 30$ & 0.20 & $-114,000$ & -7170 & $-430,200$ & 61.1 \\
\hline $2 / 27 / 17$ & $22: 30$ & $22: 56$ & 0.35 & $-114,000$ & -7520 & $-451,200$ & 65.1 \\
\hline $2 / 27 / 17$ & $22: 59$ & $23: 27$ & 0.48 & $-113,000$ & -7660 & $-459,600$ & 68.0 \\
\hline $2 / 27 / 17$ & $23: 28$ & $23: 52$ & 0.58 & $-99,300$ & -5720 & $-343,200$ & 60.2 \\
\hline $2 / 27 / 17$ & $23: 53$ & $0: 17$ & 0.67 & $-84,800$ & -3720 & $-223,200$ & 49.8 \\
\hline $2 / 28 / 17$ & $0: 17$ & $0: 40$ & 0.72 & $-67,900$ & -2310 & $-138,600$ & 43.3 \\
\hline $2 / 28 / 17$ & $0: 41$ & 1:06 & 0.76 & $-53,200$ & -1640 & $-98,400$ & 38.1 \\
\hline $2 / 28 / 17$ & $1: 07$ & $1: 31$ & 0.76 & $-18,200$ & -427 & $-25,620$ & 41.1 \\
\hline $2 / 28 / 17$ & $1: 34$ & $2: 00$ & 0.70 & 7350 & 420 & 25,200 & 38.3 \\
\hline $2 / 28 / 17$ & $2: 02$ & $2: 30$ & 0.61 & 43,400 & 1720 & 103,200 & 37.0 \\
\hline
\end{tabular}


Acknowledgements The authors wish to acknowledge past and present members of the Estuarine Sediment Transport Project and others at the USGS for their support in data collection, including Paul Buchanan, Gwen Davies, Brian Downing, Darin Einhell, Daniel Livsey, Scott Nagel, and Kurt Weidich. The authors thank Lester McKee and Phil Trowbridge of San Francisco Estuary Institute, Mark Stacey of UCBerkeley, and David Stevens of Utah State University for their support in data collection. The authors thank the Romberg-Tiburon Institute of San Francisco State and the two captains of their $R / V$ Questuary, David Bell and David Morgan. The use of firm, trade, and brand names is for identification purposes only and does not constitute endorsement by the USGS.

Funding Funding provided by the San Francisco Bay Water Quality Improvement Fund through EPA Region 9 and the San Francisco Estuary Partnership. Funding also provided by the Regional Monitoring Program for Water Quality in San Francisco Bay.

Open Access This article is licensed under a Creative Commons Attribution 4.0 International License, which permits use, sharing, adaptation, distribution and reproduction in any medium or format, as long as you give appropriate credit to the original author(s) and the source, provide a link to the Creative Commons licence, and indicate if changes were made. The images or other third party material in this article are included in the article's Creative Commons licence, unless indicated otherwise in a credit line to the material. If material is not included in the article's Creative Commons licence and your intended use is not permitted by statutory regulation or exceeds the permitted use, you will need to obtain permission directly from the copyright holder. To view a copy of this licence, visit http://creativecommons.org/licenses/by/4.0/.

\section{References}

Barnard, P.L., D.H. Schoellhamer, B.E. Jaffe, and L.J. McKee. 2013. Sediment transport in the San Francisco Bay Coastal System: an overview. Marine Geology 345: 3-17.

Burchard, H., H.M. Schuttelaars, and D.K. Ralston. 2018. Sediment trapping in estuaries. Annual Review of Marine Science 10 (1): 371-395. https://doi.org/10.1146/annurev-marine-010816-060535.

CDWR (California Department of Water Resources), 1986. DAYFLOW computer program documentation and data summary user's guide. Sacramento, California: California Department of Water Resources, https://water.ca.gov/Programs/Environmental-Services/ Compliance-Monitoring-And-Assessment/Dayflow-Data, accessed $7 / 8 / 19$.

CDWR (California Department of Water Resources), 2018. Hydroclimate report water year 2017. Sacramento, California: California Department of Water Resources, http://www.water.ca. gov/climate-meteorology.

Chen, C. 1991. Unified theory on power laws for flow resistance. Journal of Hydraulic Engineering 117 (3): 371-389.

Conomos, T.J. 1979. Properties and circulation of San Francisco Bay waters. In San Francisco Bay, the urbanized estuary, ed. T.J. Conomos. San Francisco: Pacific Division of the American Association for the Advancement of Science.

Davis, B.E. 2005. A Guide to the Proper Selection and Use of Federally Approved Sediment and Water-Quality Samplers: U.S. Geological Survey Open-File Report 2005-1087, 20 p.

Downing-Kunz, M., D. Schoellhamer, and P. Work. 2018. ADCP data in support of water and suspended-sediment flux measurements at the
Golden Gate, 2016-2017. U.S. Geological Survey data release. https://doi.org/10.5066/F7639P1N.

Edwards, T.K., and G.D. Glysson. 1999. Field methods for measurement of fluvial sediment. In U.S Geological Survey Techniques of WaterResource Investigations, book 3, Applications of Hydraulics, chap. C2 (rev.), 89 pp. Available at http://pubs.usgs.gov/twri/twri3-c2/.

Erikson, L.H., S.A. Wright, E. Elias, D.M. Hanes, D.H. Schoellhamer, and J. Largier. 2013. The use of modeling and suspended-sediment concentration measurements for quantifying net suspendedsediment transport through a large tidally dominated inlet. Marine Geology 345: 96-112.

Federal Interagency Sedimentation Project, 2001. The US D-96: an isokinetic suspended-sediment/water-quality collapsible-bag sampler, Interagency Report PP: Vicksburg, MS, Waterways Experiment Station, $37 \mathrm{p}$.

Ganju, N.K., and D.H. Schoellhamer. 2006. Annual sediment flux estimates in a tidal strait using surrogate measurements. Estuarine, Coastal and Shelf Science 69 (1-2): 165-178.

Gartner, J.W. 2004. Estimating suspended solids concentrations from backscatter intensity measured by acoustic Doppler current profiler in San Francisco Bay, California. Marine Geology 211 (3-4): 169187.

Geyer, W.R., and P. MacCready. 2014. The estuarine circulation. Annual Review of Fluid Mechanics 46 (1): 175-197. https://doi.org/10. 1146/annurev-fluid-010313-141302.

Geyer, W.R., P.S. Hill, and G.C. Kineke. 2004. The transport, transformation and dispersal of sediment by buoyant coastal flows. Continental Shelf Research 24 (7-8): 927-949.

Grant, W.D., and O.S. Madsen. 1986. The continental-shelf bottom boundary layer. Estuarine circulation. Annual Review of Fluid Mechanics 18 (1): 265-305. https://doi.org/10.1146/annurev.fl.18. 010186.001405 .

Jay, D.A., and J.D. Musiak. 1994. Particle trapping in estuarine turbidity maxima. Journal of Geophysical Research 99: 20446-20461.

Landers, M.N., T.D. Straub, M.S. Wood, and M.M. Domanski. 2016. Sediment acoustic index method for computing continuous suspended-sediment concentrations: U.S. Geological Survey Techniques and Methods, book 3, chap. C5, 63 p. https://doi.org/ $10.3133 / \mathrm{tm} 3 \mathrm{C} 5$.

Livsey, D.N. and Downing-Kunz, M.A., 2020. A summary of waterquality monitoring in San Francisco Bay in water year 2017. U.S. Geological Survey Scientific Investigations Report 2020-5064, 78p, https://doi.org/10.3133/sir20205064.

McKee, L.J., N.K. Ganju, and D.H. Schoellhamer. 2006. Estimates of suspended sediment entering San Francisco Bay from the Sacramento and San Joaquin Delta, San Francisco Bay, California. Journal of Hydrology 323 (1-4): 335-352.

McKee, L.J., M. Lewicki, D.H. Schoellhamer, and N.K. Ganju. 2013. Comparison of sediment supply to San Francisco Bay from watersheds draining the Bay Area and Central Valley of California. Marine Geology 345: 47-62.

Mueller, D.S., and Wagner, C.R., 2009. Measuring discharge with acoustic Doppler current profilers from a moving boat. Chapter 22 of Book 3, Section A, Techniques and Methods 3-A22, U.S. Dept. of Interior, U.S. Geological Survey, 86 pp.

Porterfield, G., 1980. Sediment transport of streams tributary to San Francisco, San Pablo, and Suisun Bays, California, 1909-1966: U.S. Geological Survey Water-Resources Investigations 80-64, 91 pp.

Rasmussen, P.P., Gray, J.R., Glysson, G.D., and Ziegler, A.C., 2009. Guidelines and procedures for computing time-series suspendedsediment concentrations and loads from in-stream turbidity-sensor and streamflow data: U.S. geological survey techniques and methods, book 3, chap. C4, $52 \mathrm{p}$.

Ruhl, C.A., D.H. Schoellhamer, R.P. Stumpf, and C.L. Lindsay. 2001. Combined use of remote sensing and continuous monitoring to 
analyze the variability of suspended-sediment concentrations in San Francisco Bay, California. Estuarine, Coastal and Shelf Science 53 (6): 801-812.

Schoellhamer, D.H. 2001. Influence of salinity, bottom topography, and tides on estuarine turbidity maxima in northern San Francisco Bay. In Coastal and estuarine fine sediment transport processes, ed. W.H. McAnally and A.J. Mehta, 343-357. Elsevier Science B.V.

Schoellhamer, D.H. 2002. Variability of suspended-sediment concentration at tidal to annual time scales in San Francisco Bay, USA. Continental Shelf Research 22 (11-13): 1857-1866.

Schoellhamer, D.H. 2011. Sudden clearing of estuarine waters upon crossing the threshold from transport to supply regulation of sediment transport as an erodible sediment pool is depleted: San Francisco Bay, 1999. Estuaries and Coasts 34 (5): 885-899.

Schoellhamer, D.H., Lionberger, M.A., Jaffe, B.E., Ganju, N.K., Wright, S.A., and Shellenbarger, G.G., 2005. Bay sediment budgets: sediment accounting 101: the pulse of the estuary: monitoring and managing water quality in the San Francisco Estuary, San Francisco Estuary Institute, Oakland, California, p. 58-63. Available online at: https://ssl.sfei.org/sites/default/files/biblio_files/RMP05 PulseoftheEstuary.pdf, accessed 13 Feb 2020.

Schoellhamer, D., McKee, L., Pearce, S., Kauhanen, P., Salomon, M., Dusterhoff, S., Grenier, L., Marineau, M., and Trowbridge, P., 2018.
Sediment supply to San Francisco Bay, Water Years 1995 through 2016: data, trends, and monitoring recommendations to support decisions about water quality, tidal wetlands, and resilience to sea level rise. Published by San Francisco Estuary Institute (SFEI), Richmond, CA. SFEI Contribution Number 842.

Simpson, M.R., and R.N. Oltmann. 1993. Discharge-measurement system using an acoustic Doppler current profiler with applications to large rivers and estuaries. Water Supply Paper 2395. https://doi.org/ 10.3133/wsp2395.

Simpson, J.H., J. Brown, J. Matthews, and G. Allen. 1990. Tidal straining, density currents, and stirring in the control of estuarine stratification. Estuaries 13 (2): 125-132.

Teeter, A.M., Letter, J.V., Pratt, T.C., Callegan, C.J., Boyt, W.L., 1996. San Francisco Bay long-term management strategy (LTMS) for dredging and disposal. Report 2. Baywide suspended sediment transport modeling. Technical Report \#A383413. Army Engineer Waterways Experiment Station, Hydraulics Lab, Vicksburg, MS.

Teledyne RD Instruments, 2016. WinRiver II Software user's guide. P/N 957-6231-00. $298 \mathrm{p}$.

Wall, G.R., E.A. Nystrom, and S. Litten. 2006. Use of an ADCP to compute suspended-sediment discharge in the tidal Hudson River. New York: U.S. Geological Survey Scientific Investigations Report 2006-5055, 16 p. 